\title{
Systematic paleontology and taphonomic studies of Ypresian mollusks at the Kopet-Dagh Basin, NE Iran
}

\author{
Amir Salahi, Abbas Ghaderi, Ali Reza Ashouri, Alejandro Gristín, Saeedeh Senemari
}

\begin{abstract}
Amir Salahi
Abbas Ghaderi

aghaderi@um.ac.ir

Ali Reza Ashouri

Department of Geology, Faculty of Sciences, Ferdowsi University of Mashhad, Azadi Square, 9177948974, Mashhad, Iran.
\end{abstract}

\section{Alejandro Gristín \\ Posgrado en Ciencias de la Tierra, Instituto de Geología, Universidad Nacional Autóno- ma de México, Goyoacán, 04510, CDMX, Mexico.}

\section{Saeedeh Senemari}

Faculty of Technical \& Engineering, Imam Khomeini International University, 3414896818 Qazvin, Iran.

BOL. SOC. GEOL. MEX. 2019

VOL. 71 NO. 3

P. $773-804$

http://dx.doi.org/10.18268/BSGM2019v7 ln3a9

Manuscript received: September 9, 2018. Corrected manuscript received: December 20, 2018 Manuscript accepted: January 22, 2019.

\begin{abstract}
Marine invertebrate fossils have long been considered important tools for age dating and stratigraphic interpretation of the Paleogene deposits of Central Asia, however information has not yet been provided from the Kopet-Dagh Basin (NE Iran). In this research, fossiliferous horizons of the Chehelkaman Formation at the Sheikh and Ghaleh-Zou sections (which have never been recognized previously), both in the Sheikh Syncline area, are discussed. These sedimentary beds overlay the terrestrial siliciclastic Pesteligh Formation and are the first evidence of marine flooding of the Paleogene transgression in the central Kopet-Dagh. Systematic paleontological studies of molluscan fossils in this succession led to the identification of ten genera, twelve species and two subspecies of bivalves and five genera and five species of gastropods. The assemblage belongs to four different fossiliferous horizons: (1) Turritellidae Dominated Assemblage (TDA), (2) Pycnodonte - Turkostrea horizon, (3) Cordiopsis - Cardium horizon and (4) Globularia shell beds in the Sheikh section and only TDA horizon in the Ghaleh-Zou section. The age of the whole succession, based on Cordiopsis subathooensis - Turritella subathooensis Zone co-occurrence with nannofossil zones NP12 and NP13, is Late Ypresian (early middle Cuisian). The TDA in both sections confirms the abundance of nutrients and their bimodal orientation demonstrates effects of oscillatory waves rather than unidirectional paleo-currents. High rates of bioerosion, encrustation, fragmentation, disarticulation and corrosion of the shells in the Pycnodonte - Turkostrea horizon reveals high volumes of nutrients and energy-rich conditions. This interval, overlain by the Cordiopsis - Cardium horizon in a pavement arrangement, represents the stable conditions after a storm. The Globularia shell beds interbedded with marly beds indicate stability and a deepening trend of the environment, terminating to deeper marine shales and marls of the Khangiran Formation.
\end{abstract}

Keywords: Taphonomy, paleoenvironment, Early Eocene, Kopet-Dagh Basin, Chehelkaman Formation.

\section{RESUMEN}

Los fósiles de invertebrados marinos se han considerado herramientas importantes para la recolecta de datos por edades y la interpretación estratigráfica de los depósitos de paleógenos de Asia Central, sin embargo, aún no se ha proporcionado información de la cuenca de KopetDagh (NE Irán). En esta investigación, se discuten los horizontes fosiliferos de la Formación Chehelkaman en las secciones Sheikh y Ghaleh-Zou (que nunca antes se habian reconocido), ambos en el área Sheikh Syncline. Estos lechos sedimentarios se superponen a la Formación de Pesteligh siliciclástica terrestre y son la primera evidencia de inundación marina de la transgresión del Paleógeno en el centro de Kopet-Dagh. Los estudios paleontológicos sistemáticos de fósiles de moluscos en esta sucesión condujeron a la identificación de: diez géneros, doce especies, dos subespecies de bivalvos, cinco géneros y cinco especies de gasterópodos. El conjunto pertenece a cuatro horizontes fosiliferos diferentes: (1) Conjunto Dominado por Turritellidae (TDA), (2) Pycnodonte - Turkostrea horizonte, (3) Cordiopsis - Cardium horizonte, (4) Camas de concha Globularia en la sección Sheikh y solo horizonte TDA en la sección de Ghaleh-Zou. La edad de toda la sucesión es 1presian tardio (Cuisian medio temprano). Ésta edad está basada en Cordiopsis subathooensis Turritella subathooensis co-ocurrencia de la zona con las zonas de nannofósiles NP12 y NP13. El TDA en ambas secciones confirma la abundancia de nutrientes y su orientación bimodal demuestra los efectos de las ondas oscilatorias en lugar de las paleocorrientes unidireccionales. Las altas tasas de bioerosión, incrustación, fragmentación, desarticulación y corrosión de las conchas en Pycnodonte - Turkostrea horizonte revela altos volúmenes de nutrientes y condiciones ricas en energía. Este intervalo, cubierto por la Cordiopsis - Cardium horizonte en una disposición de pavimento, representa las condiciones estables después de una tormenta. Los lechos de conchas de Globularia intercalados con lechos de marga, indican estabilidad y una tendencia cada vez más profunda del medio ambiente terminando en lutitas y margas más profundas de la Formación Khangiran.

Palabras clave: Tafonomía, paleo-ambiente, Eoceno temprano, cuenca de Kopet-Dagh, Formación Chehelkaman. 


\section{Introduction}

The Kopet-Dagh Mountains of north-eastern Iran had long been recognized as a petroliferous basin (Afshar-Harb, 1969). These Mountains extend from the eastern margin of the Caspian Sea to Afghanistan, limited by the Ashgabat fault at the northern border and the Alborz Range and Central Iran from the southern part (AfsharHarb, 1979; Buryakovsky et al., 2001). The basin was formed as a result of the southeastern extension of the South Caspian Basin by Neotethyan back-arc rifting, followed by the closure of the Palaeotethys in the Middle Triassic by the Early Cimmerian Orogeny (Robert et al., 2014). In the basin, continuous sedimentation took place from the Jurassic to the Neogene (Berberian and King, 1981; Afshar-Harb, 1994; Garzanti and Gaetani, 2002; Wilmsen et al., 2009; Robert et al., 2014).

The Paleogene rocks of this sedimentary basin are Early to early Middle Paleocene Pesteligh Formation (Robert et al., 2014), the Middle Paleocene - Early Eocene Chehelkaman Formation (Rivandi et al., 2012), and the Eocene - Early Oligocene Khangiran Formation (Hadavi and Senemari, 2002). These successions are overlain by unnamed continental Neogene red beds and Quaternary alluvial deposits (Saadat-Mehri et al., 2012).

The Chehelkaman Formation is a fossil rich rock unit with nannoplankton, foraminifers, dinoflagellates, ostracods, fish remains and a molluscan assemblage (Hadavi and Senemari, 2002; Salahi, 2011; Moshirfar et al., 2013; Rivandi et al., 2013).

The formation is useful and informative for stratigraphic correlation within the basin and also with the Central Asia region. Nonetheless, the macrofossil content of this formation has previously never been investigated. The only published report on the molluscan fossils of the Paleogene succession of the Kopet-Dagh Basin is from Salahi and Vahidinia (2011), who focused on the Lutetian- Bartonian oysters of the upper part of the Khangiran Formation. In the current research, we carry out the systematic paleontological, paleoecological and paleoenvironmental interpretation of the molluscan fossils of the Chehelkaman Formation in the Sheikh Syncline area (SSA), which is located at the northeast of Bojnourd City in the central Kopet-Dagh (Figure 1).

\section{Geological setting}

During the Early Paleocene, the Laramide orogeny caused the retreat of the sea, followed by continental deposits of the Pesteligh Formation above the completely marine Kalat Formation (Afshar-Harb, 1994; Robert et al., 2014). The red beds of the Pesteligh Formation in the type area of the eastern Kopet-Dagh gradually change to alternating siliciclastic and carbonate beds of the Chehelkaman Formation, which indicates the first phase of the Paleogene sea transgression. Toward the upper part, gradual change in the lithology from the limestone into silty marl and marl are characteristic for the Khangiran Formation.

Along the central part of the basin, particularly in the SSA, it is difficult to follow the typical succession of the Paleogene and Neogene rock units laterally because of its lateral facies changes than the type locality area. The shallowing trend toward the central Kopet-Dagh Basin and replacement of the carbonate sequence by siliciclastic-evaporitic succession is the most important feature of the depositional system. These facies changes cause some difficulties for stratigraphic interpretations; therefore the Chehelkaman Formation has never been depicted in the published reports of the area (e.g., Afshar-Harb, 1979, 1994). It was also not mentioned in the geological maps of the area, such as 1/250,000 quadrangle map of Bojnourd (Bolourchi and Afshar-Harb, 1987) and 1/100,000 quadrangle map of Kakli (Ghaemi, 2004). It means the previous geologists depicted the Khangiran Formation directly on the Pesteligh Formation through a main stratigraphic gap, which was considered temporally equivalent to the depositional interval of the Chehelkaman Formation in the type locality area in the eastern Kopet-Dagh Basin. 


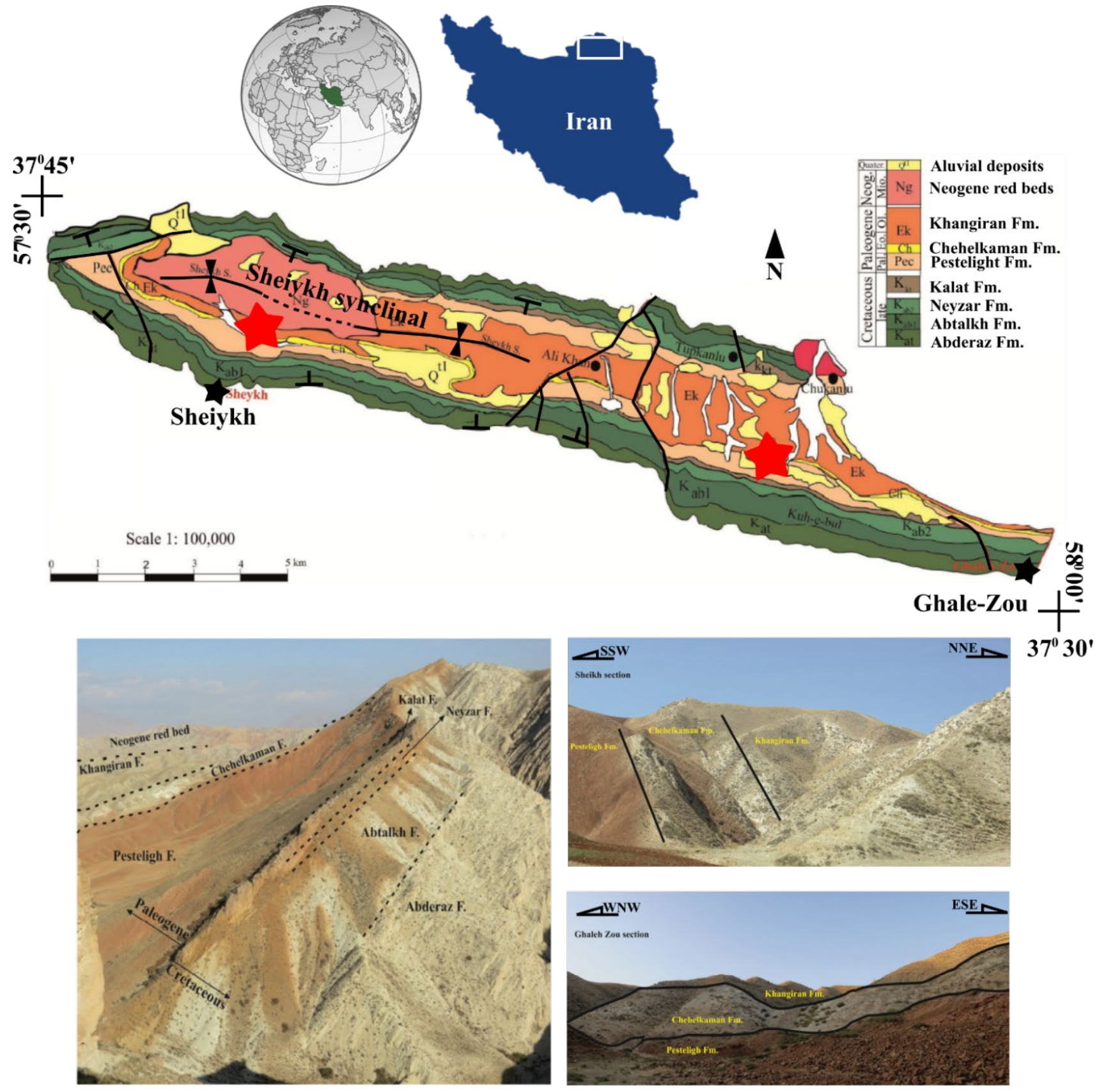

Figure 1 Geological map of the studied area in central part of the Kopet-Dagh Basin; red stars point to the sections discussed (modified after Afshar-Harb, 1982). Left photograph: Outcrop at Sheikh Synclinal region with sequence of lithostratigraphic units from Upper Cretaceous to Neogene. Right upper photograph: stratigraphic section at the Sheikh area. Right lower photograph: stratigraphic section at the Ghlaeh-Zou area. 
The fossiliferous beds in the SSA have been investigated in two stratigraphic sections, $22 \mathrm{~km}$ apart (Figures 1 and 2). The Sheikh section in the western part of the SSA is located between the coordinates N37 34 '42" and E57³248" and the Ghaleh-Zou section in the southeastern part of the SSA, between the coordinates $\mathrm{N} 37^{\circ} 31^{\prime} 40.7^{\prime \prime}$ and E57\%47'13.2". Our fieldwork in both sections confirms the presence of the Chehelkaman Formation shell beds, but in much less thickness than the type section area (Figure 1). Like typical shell beds (Kidwell et al., 1986), they are laterally well-extended and show a high abundance of macrofossils.

\section{Sheikh section}

\section{Material and Methods}

Amongst the collected bivalve and gastropod specimens, the best preserved were selected for systematic description. They were biometrically measured and their shape, outline, shell thickness, ornamentations, convexity, ribs and growth lines were determined and compared with the published descriptions of the known fauna from the other regions, especially Central Asia (Berizzi Quarto di Palo, 1970; Lan, 1997; Mathur and Juyal, 2000; Halder and Sinha, 2014). In addition, depositional and ecological conditions of the formation of

\section{Ghaleh Zou section}

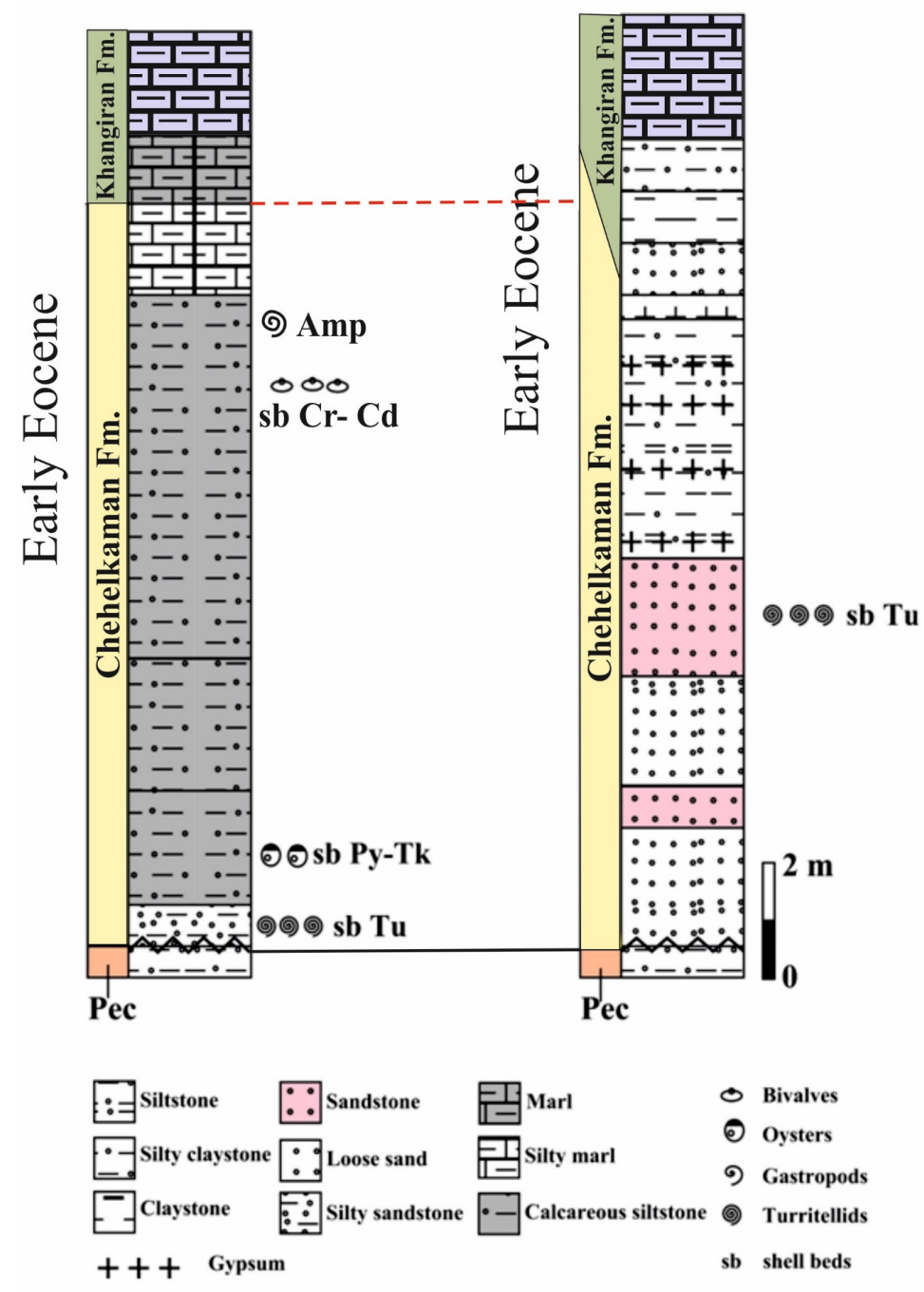

Figure 2 Stratigraphic logs at the Sheikh and Ghaleh-Zou sections. 
shell beds (Dorsey and Kidwell, 1999; Dorsey and Umhoefer, 2000) and taphonomic attributes of macrofossils such as transportation, fragmentation, disarticulation, corrosion, encrustation, boring, and predation were recorded (Gordillo et al., 2014). The shells of turritelline were classified following Allmon et al. (1995) in two classes as complete and incomplete specimens. The complete shells have three to five whorls preserved and variable diameter of the twisting. Photographs were taken using a Cannon 60D camera and macro lens L100.

\section{Results}

\subsection{SHEIKH SECTION}

In the Sheikh section, the sedimentary sequence includes Cenozoic sedimentary units, from the Pesteligh Formation to Neogene red beds, with a total thickness of $774 \mathrm{~m}$. This study was carried out on only $20 \mathrm{~m}$ of the upper part of the Pasteligh Formation to the lower part of the Khangiran Formation (Figure 2).

\subsubsection{PESTELIGH FORMATION}

The formation is characterized by $250 \mathrm{~m}$ of medium to thick planar-parallel bedsets of siltstone, sandstone, claystone, and interbedded thin gypsum layers. Some charophyte remains were recorded from the top claystone horizons (Figure 3). This flora was deposited in a freshwater environment.

\subsubsection{CHEHELKAMAN FORMATION}

The Chehelkaman Formation is mainly composed of fossiliferous and porous limestone, siltstone, calcareous sandstone, interbedded marl and evaporites. The top of the formation is composed of calcareous shell beds, siltstone and calcareous sandstone, with many mollus-
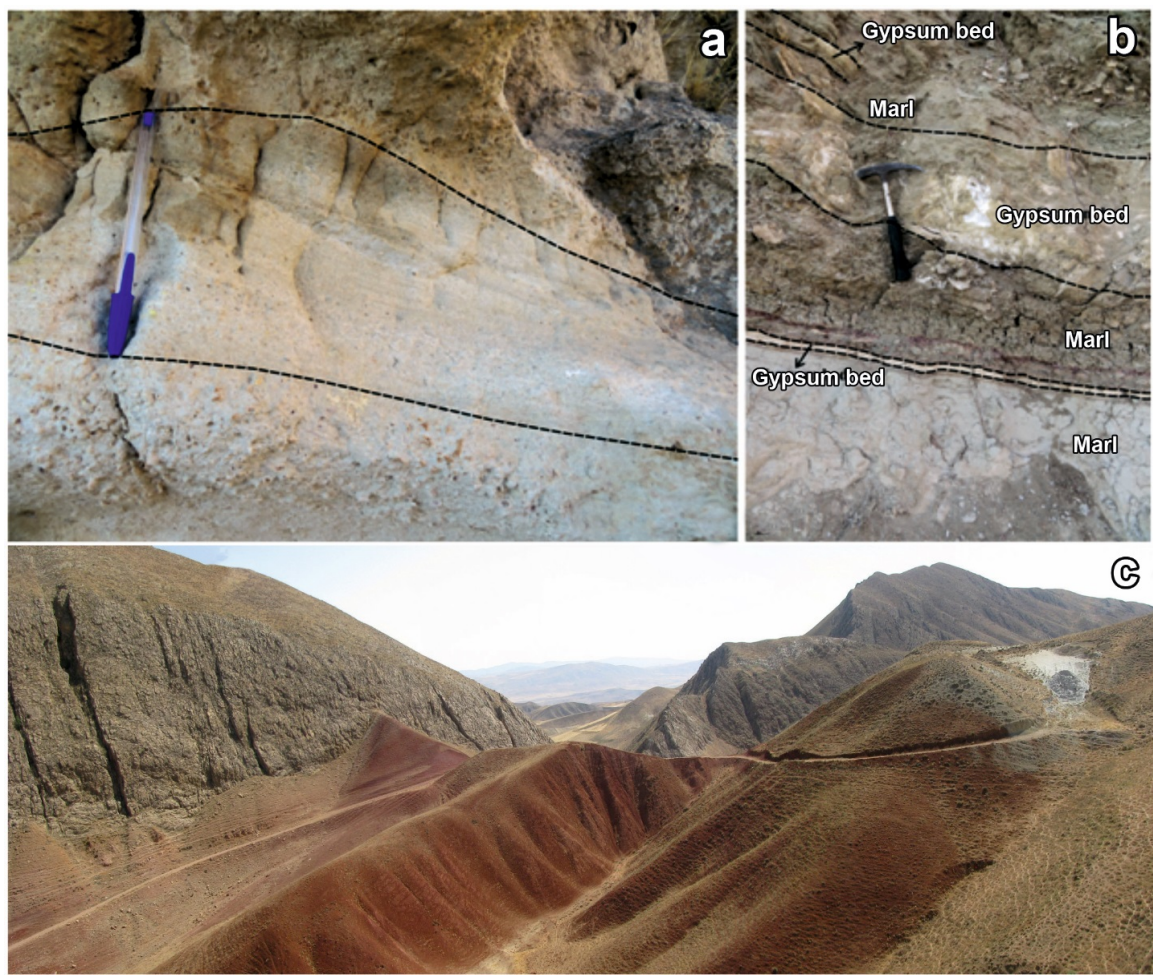

Figure 3 a: Sandy beds of Chehelkaman Formation in the Ghaleh-Zou section with turritelines at the lowermost and uppermost of the bed; b: Silty marls and gypsum beds in the boundary between Chehelkaman and Khangiran formations in the Ghaleh-Zou section; c: Lateral outcrops of Chehelkaman Formation in SSA region; as it is clear in the figure, the formation totally turns to evaporatic facies. This facies change was probably the main reason of neglected Chehelkaman Formation definition in the previous studies. 
can fossils. The thickness of this formation is up to $300 \mathrm{~m}$, while in the type section area at the Eastern Kopet-Dagh it is $234 \mathrm{~m}$ (Afshar-Harb, 1994).

In the Sheikh section, the formation is represented by $14 \mathrm{~m}$ of medium to thick, planar-parallel, silty to sandy white limestone, shell beds, sandstone and silty marl beds, with abundant molluscan fossils (Figure 2). This unit overlays directly the Pesteligh Formation and underlies the silty and marly Khangiran Formation. Its lower boundary with the Pesteligh Formation is sharply erosive, but its upper boundary with the Khangiran Formation is in a fining upward trend to the marine silty marls beds of the Khangiran Formation (Figure 2). The fossil rich beds, especially those with ampulinid gastropods, are associated to the uppermost part of the Chehelkaman Formation in both the type section and the Sheikh section.

\subsubsection{KHANGIRAN FORMATION}

The Khangiran Formation is composed of $270 \mathrm{~m}$ of gray to green, medium to thick planar-parallel beds of siltstone, silty marl and marl beds. The geological study focused on the first 4 to $6 \mathrm{~m}$ above the lower boundary.

\subsection{GHALEH-ZOU SECTION}

The Paleogene sedimentary sequence in the Ghaleh-Zou section comprises the Pesteligh Formation to the Neogene red beds with a total thickness of $774 \mathrm{~m}$. In this research, only $18 \mathrm{~m}$ of the Pesteligh Formation upper parts to the lower beds of the Khangiran Formation have been studied (Figure 2).

\subsubsection{PESTELIGH FORMATION}

This unit is characterized by bedsets of siltstone, sandstone, and claystone generally of red color (Figure 3).

\subsubsection{CHEHELKAMAN FORMATION}

The Chehelkaman Formation is 12 m thick; it is composed of white sandstone and siltstone with interbedded white to gray thin-bedded sandstone, and lamina sets of gypsum varying from 2 to $8 \mathrm{~cm}$ thick. These gypsum sets become laterally thicker to evaporitic beds (Figure 4). This unit shows the medium to thick beds of loose and non-loose sandstone, both types of beds with curved, non-parallel lamination (Figure 4). Turritelline gastropods are only found in these sandy beds. The boundary of the Chehelkaman and the Khangiran formations is characterized by a gradual fining upward, comprehending terrigenous, evaporitic and marly rocks.

\subsubsection{KHANGIRAN FORMATION}

The formation is $270 \mathrm{~m}$ thick, consisting of medium to thick beds of siltstone, silty marl, and marl which show continuous, planar and parallel lamination. The lower part of the formation consists of evaporitic beds interbedded with silty marl and marly beds (Figure 4), ranging from thin laminae to thick beds in white to gray color. From the basal part of this formation, abundant nannofossils were obtained. Comments. - Most of the sedimentary rocks in the eastern SSA were deposited in a marine environment, as it is comprehensible from the lithology and fossil evidence (e.g., shell beds). The Chehelkaman Formation likely formed in subaqueous conditions, from very shallow subtidal to sabkha environments. The calcareous algae remains from the Khangiran Formation and the presence of a considerable amount of glauconite suggest deeper conditions, likely subtidal, implying a sea level rising. The nannofossils determined an age interval from NP12 to NP13 (Early Eocene), for the Chehelkaman Formation and the lower part of the Khangiran Formation. This age interval will be discussed below.

\section{Systematic Paleontology}

Phylum Mollusca Linnaeus, 1758

Class Bivalvia Linnaeus, 1758

Order Ostreoidea Rafinesque, 1815

Family Gryphaeidae Vialov, 1936

Genus Pycnodonte Fischer von Waldheim, 1835

\section{Pycnodonte sp.}

Figure 5.1 

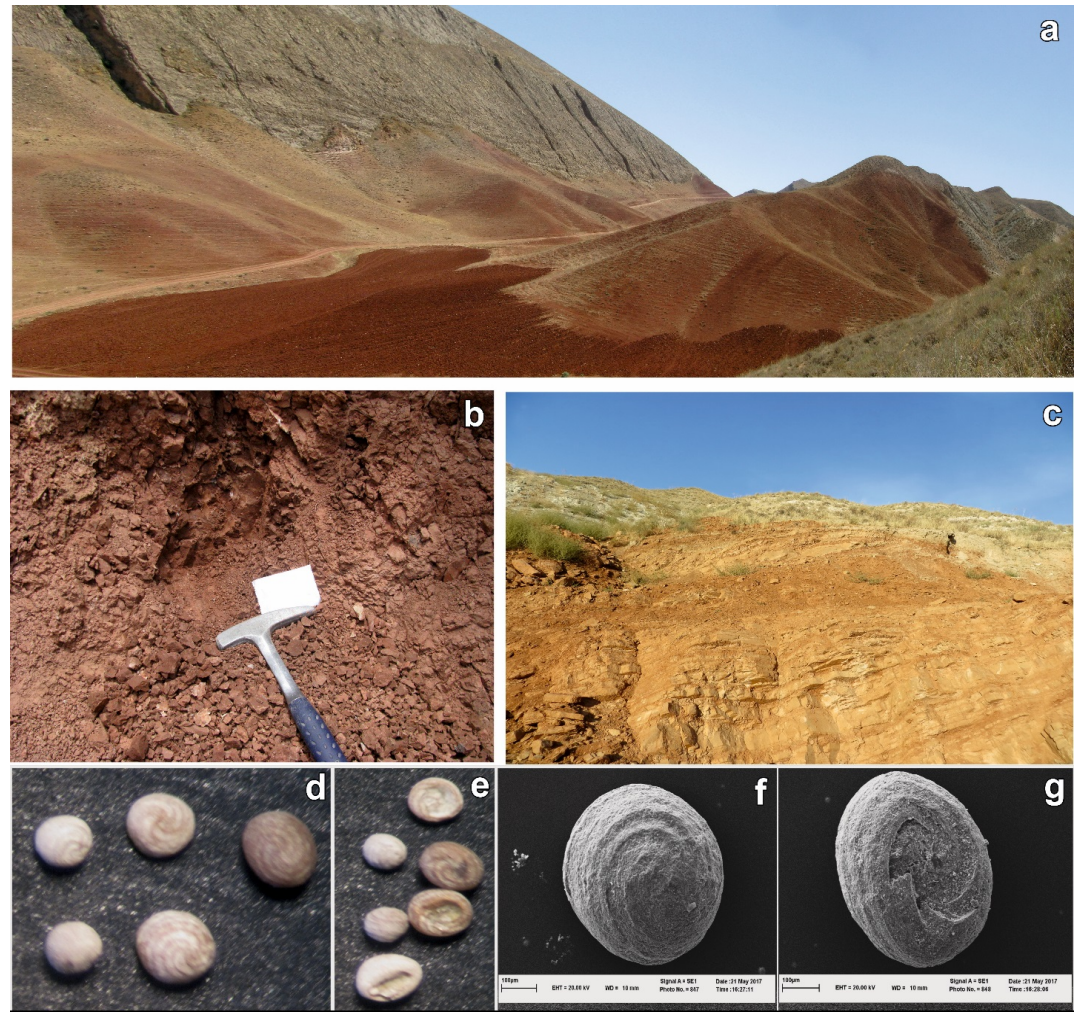

Figure 4 Pesteligh Formation in the SSA. a-b: Sheikh section; c: Ghaleh-Zou section; d-g: Charophyts algal remains from the Pesteligh Formation in light microscope and SEM images.

Material: five left valves, MASSH 0001 - MASSH 0005.

Stratigraphic occurrence in the Kopet-Dagh Basin: Chehelkaman Formation, Sheikh section, horizon 1 at $0.3 \mathrm{~m}$ from the base, horizon 2 at $1.1 \mathrm{~m}$ from the base, horizon 3 at $9 \mathrm{~m}$ from the base.

Description.- Relatively thick shell of medium size, subcircular to ovate in outline to dorsoventrally elongate, higher than long and highly convex. Specimens show a broad but broken posterior flange. Convex cup-like and generally smooth left valve with very fine concentric growth squamae and traces of a few discontinuous radial ribs in the umbonal region. Triangular ligament area (gryphaeoid type), mostly longer than high with flat bourelets that are shorter in length to the resilifer. Catachomata is absent, but vermiculate-chomata are present. Vermiculate chomata short, rather shallow, hardly visible; muscle scar is not visible due to covering by chalky sediments. Attachment area very small to absent. Vesicular layers not rec- ognized. Umbo relatively small, subcircular and slightly opisthogyral.

Dimensions. - valve length (L) $48 \mathrm{~mm}$, valve height $(\mathrm{H})$ $74 \mathrm{~mm}$ and maximum shell thickness of left valve 27 $\mathrm{mm}$.

Taxonomic comments. - Based upon shell structure, smoother cuplike shell, shell height, triangular gryphaeoid type ligament with flat bourelets, presence of flange, types of chomata and the poor development of the ribs and attachment area (Stenzel, 1971; Machalski, 1988; Callapez et al., 2015) the specimens are representatives of the gryphaeid genus Pycnodonte.

Family Ostreidae Rafinesque, 1815

Subfamily Ostreinae Rafinesque, 1815

Genus Ostrea Linnaeus, 1758

Subgenus Turkostrea Vialov, 1936

Ostrea (Turkostrea) turkestanensis turkestanensis (Romanovskiy, 1878)

Figures $5.2 \mathrm{a}$ and $5.2 \mathrm{~b}$ 


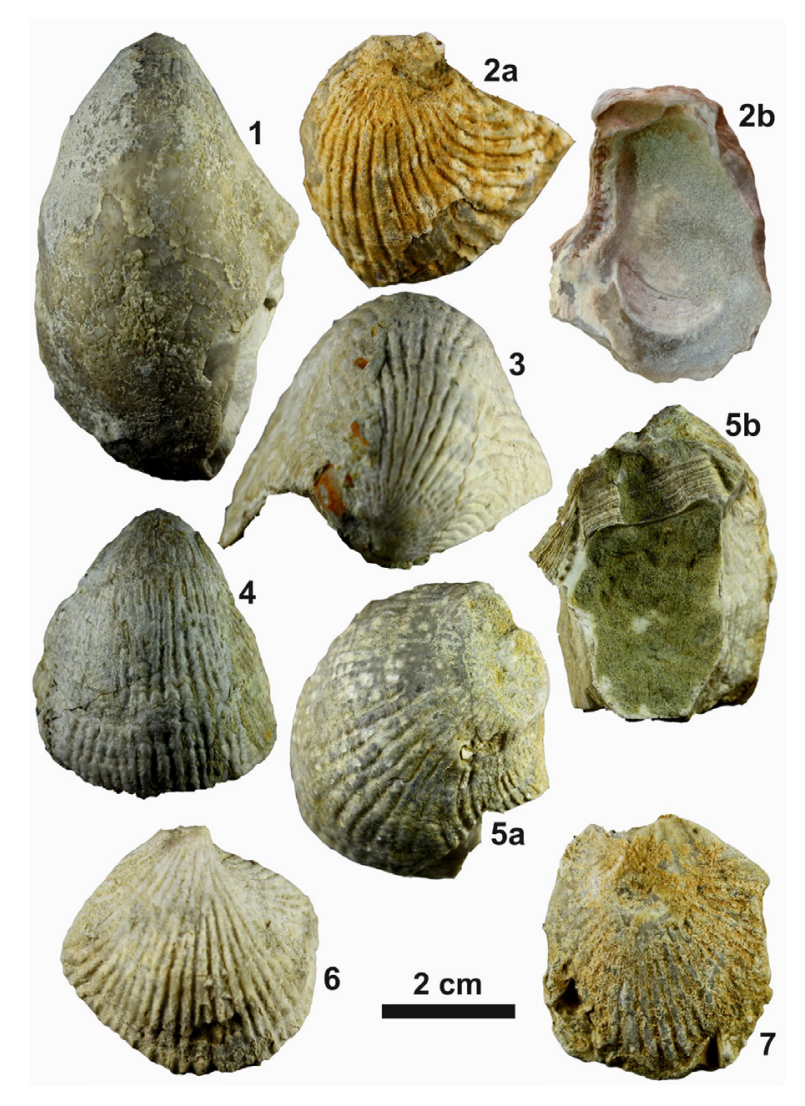

Figure 5 1: Pycnodonte sp., \#MASSH0003; 2a-2b: Ostrea (Turkostrea) turkestanensis turkestanensis, \#MASSH 0031 - 0032; 3, 4, 5a-5b: Ostrea (Turkostrea) turkestanensis baissunensis, \# MASSH 0020 - 0022; 6, 7: Ostrea (Turkostrea) afghanica, \#MASSH 0006 - 0009 ; all specimens from Chehelkaman Formation, Sheikh section.

1948 Ostrea turkestanensis, Vialov, Pl. XXII, figs. 2-4

1962 Ostrea turkestanensis, Gekker, Osipova, Belskaya, Pl. V, figs. 1-3

1970 Ostrea (Turkostrea) turkestanensis turkestanensis, Berizzi Quarto di Palo, Pl. 33, fig. 2; Pl. 34, fig. 3; Pl. 35, figs. 2-3

Material: two left valves, MASSH 0031 - MASSH 0032 .

Stratigraphic occurrence in the Kopet-Dagh Basin: Chehelkaman Formation, Sheikh section, horizon 1 at $1.1 \mathrm{~m}$ from the base.

Description. - Thick shell with small size, inequivalve, oval to subtriangular, moderately to strongly convex, with very strong convexity in median region. Massive with narrow umbonal region and inclined apex, sculptured left valve with regular, almost equal and symmetric radial ribs with equal interspace in dorsal view, wider toward the valve margin, rather deep and narrow curved posteriorly.

The number of radial ribs is 22 to 28. Concentric growth lamellae, more noticeable at ventral margin. Higher than long, with small to moderately attachment area. Internal shell smooth with broad crescentic kidney-shaped muscle scar, triangular ligament area (turkostreoid type) that strongly curves posteriorly, longer than high with narrow and diagonal bourelets. Catachomata and shallow-short vermiculate-chomata are present. Vesicular layers not seen.

Dimensions. - L: $21 \mathrm{~mm}, \mathrm{H}: 22 \mathrm{~mm}$ and maximum shell thickness of left valve $7 \mathrm{~mm}$.

Taxonomic comments. - Small size, turkostreoid type of ligament area with kidney shaped muscle scar that has a semi flange in the posterior side. 
Ostrea (Turkostrea) turkestanensis baissunensis Böhm 1899

Figures 5.3, 5.4, 5.5a and 5.5b

1948 Ostrea (Turkostrea) turkestanensis baissunensis, Vialov, Pl. XXIII, figs. 1, 4

1970 Ostrea (Turkostrea) turkestanensis baissunensis, Berizzi Quarto di Palo, Pl. 36, figs. 4-7

Material: twelve left valves, MASSH 0014 - MASSH 0026.

Stratigraphic occurrence in the Kopet-Dagh Basin: Chehelkaman Formation, Sheikh section, horizon 1 at $1.1 \mathrm{~m}$ from the base.

Description.- Relatively thin to thick shell of small to medium size, moderately inequivalve and inequilateral, nearly moderately to strongly convex, subtriangular to suboval in outline. Right valve concave marked by concentric growth lines. Sculptured somewhat irregular, strong and large radial ribs on the left valve (26 numbers) with rounded tops and bifurcated with equal and narrow interspace that are wider toward the ventral margin. The internal view is not visible in all studied specimens because of sediment casing. Umbo inflated, attachment area is clearly visible, mostly extended as a relatively large area of the umbonal region. Triangular ligament area (turkostreoid type) slightly posteriorly curved, mostly longer than high. Catachomata can be seen and shallow-short vermiculate-chomata are present. Muscle scar is unknown due to coating by sediment. Vesicular layers not observed. Umbo rather big and non-coiled. Thin concentric fairly compressed growth lamellae slightly visible. Ribs particularly in the umbonal region become denser toward anterior and posterior sides. Anterior margin weakly convex, becoming a broad arc at the ventral margin. Posterior margin slightly hollowed beneath part of the umbo.

Dimensions.- Figure 12.5, L: 62 mm, H: 66 mm and maximum shell thickness of left valve $31 \mathrm{~mm}$. Figure 12.6, L: $43 \mathrm{~mm}, \mathrm{H}: 52 \mathrm{~mm}$ and maximum shell thickness of left valve $22 \mathrm{~mm}$. Figure 12.7 (broken form), L: $34 \mathrm{~mm}, \mathrm{H}: 47 \mathrm{~mm}$ and maximum shell thickness of left valve $21 \mathrm{~mm}$.
Taxonomic comments. - The specimens are larger than Ostrea afghanica and Ostrea (Turkostrea) turkestanensis turkestanensis. Ostrea turkestanensis baissunensis has more rounded and rough ribs in comparison with Ostrea afghanica and Ostrea turkestanensis turkestanensis, Convexity of left valve is generalized unlike Ostrea afghanica and Ostrea (Turkostrea) turkestanensis turkestanensis and mostly focused on the central part of the left valve. Also, a broader umbo can be seen in this subspecies. In many sections in Central Asia, the subspecies was reported from the Middle Eocene (Berizzi Quarto di Palo, 1970), but in this study we report the subspecies from the Early Eocene.

\section{Ostrea (Turkostrea) afghanica Vialov 1938}

Figures 5.6 and 5.7

1948 Ostrea (Turkostrea) afghanica, Vialov, Pl. XXV, figs. 1-3

1970 Ostrea (Turkostrea) afghanica, Berizzi Quarto di Palo, Pl. 33, figs. 3-4

Material: eight left valves, MASSH 0006 - MASSH 0013

Stratigraphic occurrence in the Kopet-Dagh Basin: Chehelkaman Formation, Sheikh section, horizon 1 at $1.1 \mathrm{~m}$ from the base.

Description. - Thin shell of small size, moderately to strongly convex, rhomboid to quadrangular with symmetric outline. Sculptured left valve with blunt, rounded and high-bifurcated radial ribs with equal interspace in dorsal view and wider toward the valve margin, rather deep and narrow; 29 radial ribs, the secondary ribs positioned on tops of primary ribs. Some specimens have a developed small to large attachment area. Triangular ligament area (turkostreoid type) posteriorly curved, mostly longer than high with narrow and diagonal bourelets. Catachomata and shallow-short vermiculate-chomata are present. Muscle scar unknown because of coating by sediment. Attachment area small to large. Vesicular layers not seen. Umbo small, relatively acute, inflated and slightly orthogyrate. 


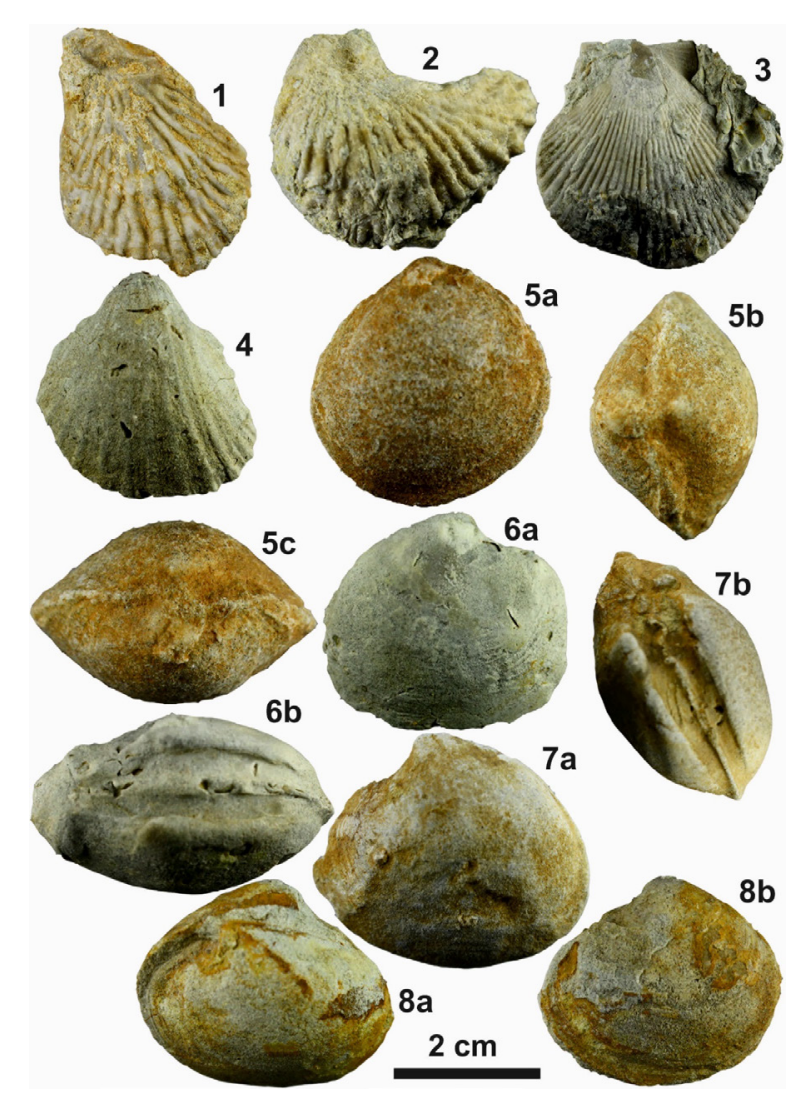

Figure 6 1: Cubitostrea sp., \#MASSH 0029; 2: Cubitostrea plicata, \#MASSH 0027; 3: Argopecten sp., \#MASSH 0036; 4: Cardium sp., \#MASSH 0038; 5a-5c: Pterolucina sp., \#MASSH 0044; 6a-6b, 7a-7b: Pelecyora (Cordiopsis) subathooensis, \#MASSH 0047- 0048; 8a-8b: Meretrix sp., \#MASSH 0052; all specimens from Chehelkaman Formation, Sheikh section.

Dimensions. - Figure 11.6, L: $28 \mathrm{~mm}, \mathrm{H}: 29 \mathrm{~mm}$ and maximum shell thickness of left valve $11 \mathrm{~mm}$. Figure 11.7, L: $21 \mathrm{~mm}, \mathrm{H}: 26 \mathrm{~mm}$ and maximum shell thickness of left valve $7 \mathrm{~mm}$.

Taxonomic comments. - Vialov (1936) and Stenzel (1971) considered Ostrea (Turkostrea) afghamica as a subgenus characterized by their oval to triangular-ovoid, strongly convex left valves. Gryphaea is homeomorphous with strong chomata, continuous radial ribs with rounded crests, and slight to strong posteriorly curved ligament area (turkostreoid type). The difference between Turkostrea and Sokolowia is the less strongly gryphaeate shape of Turkostrea (Berizzi Quarto di Palo, 1970; Griffin et al., 2005). The specimens of this subgenus in the present study are smaller, with a shell more convex, and a sharp and pointed umbo.

Subfamily Crassostreinae Torigoe, 1981 Genus Cubitostrea Sacco, 1897

\section{Cubitostrea plicata Solander 1766}

Figure 6.2

1958 Ostrea (Cubitostrea) plicata, Kljušnikov, Pl. 24, figs. 2-3

1964 Ostrea (Cubitostrea) plicata aralensis, Karagjuleva, Pl. 10, fig. 1; Pl. 12, figs. 1a-1b

1972 Ostrea cf. plicata, Kecskemétiné-Körmendy, Pl. 30, figs. 3-5

Material: two left valves, MASSH 0027 - MASSH 0028.

Stratigraphic occurrence in the Kopet-Dagh Basin: Chehelkaman Formation, Sheikh section, horizon 1 at $1.1 \mathrm{~m}$ from the base.

Description. - Small size, short, high valves ornamented with many thick ribs, curved and crescent in outline; thick left valve slightly to moderately convex, increase in height of radial ribs on left valve and progressively stronger curvature of 
shell. About 16 to 21 rough and coarse ribs that are long and radial in the irregular lines, rising of two and rarely more secondary costae that comprehensively similar to primaries can be seen. Interspace of ribs is deep and narrower than ribs, shell wider than high. The inner part of the specimens is covered by sediment, so it is impossible to check the ligament area, chomata and muscle scar. Spirogyrate umbo is slightly twisted.

Dimensions. - L: $34 \mathrm{~mm}, \mathrm{H}: 31 \mathrm{~mm}$ and maximum shell thickness of left valve $7 \mathrm{~mm}$.

Taxonomic comments. - Almost all specimens of Cubitostrea are small to medium in size and have a curved outline (Stenzel, 1971), but all of our specimens are small and show a curved and crescent shape. This genus can be separated from Sokolowia and Turkostrea by sharply triangular to sickle-shaped shell (Griffin et al., 2005). Cubitostrea contains strong radial ribs.

\section{Cubitostrea sp.}

Figure 6.1

Material: two left valves, MASSH 0029 - MASSH 0030 .

Stratigraphic occurrence in the Kopet-Dagh Basin: Chehelkaman Formation, Sheikh section, horizon 1 at $1.1 \mathrm{~m}$ from the base.

Description. - Small size, short, vertically ovate, slightly convex, sculptured with irregular rounded-thick ribs almost toward ventral side, slightly crest arched toward the margins and concentric lamellae inconspicuous. The height and rounding of the radial ribs increase on the left valve, almost 10 to 12 long and radial ribs that are in irregular lines. Rising of two or more secondary costae toward ventral side can be seen. Interspace of ribs is deep and narrower than ribs. The width of the shell is greater than the height. Inner part of specimens was coated by sediment, impossible to see the ligament area, chomata and muscle scar. An opisthogyrate umbo can be seen in this material.

Dimensions. - L: $19 \mathrm{~mm}, \mathrm{H}: 28 \mathrm{~mm}$ and maximum shell thickness of left valve $4 \mathrm{~mm}$.

Taxonomic comments. - Small sized Cubitostrea with strong radial ribs that are not curved and crescent shaped as in Cubitostrea plicata. The opisthogyrate form of umbo in this species differs from Cubitostrea plicata.

Order Pterioidea Gray, 1847

Family Pectinidae Rafinesque, 1815

Genus Argopecten Monterosato, 1889

Argopecten sp. A

Figure 6.3

Material: three left valves, MASSH 0035 - MASSH 0037.

Stratigraphic occurrence in the Kopet-Dagh Basin: Chehelkaman Formation, Sheikh section, horizon 1 at $1.1 \mathrm{~m}$ from the base.

Description.- Small convex shell, subcircular, height is slightly larger than its length. Beak rounded, protruding over the dorsal margin, auricles with similar extension and anterior auricle is broken. The posterior auricle has a straight margin and 5 to 6 fine riblets on the surface. Byssal sinus poorly preserved, but apparently shallow and wide. Commarginal lamellae poorly preserved, barely exhibited as straight outline on ribs and interspaces. Radial ribs narrow with rounded tops, wider toward the ventral margin, with a maximum of 38 ribs. The ribs of this species in cross-section are square even the interspaces is more or less square.

Dimensions. - L: $38 \mathrm{~mm}, \mathrm{H}: 37 \mathrm{~mm}$.

Taxonomic comments. - The shell convexity, orbicular outline, oblique growth, the symmetric size of the auricles, absence of interspaces riblets and the sculpture characteristics are the main features that distinguish Argopecten from the close related genus Aequipecten and other members of the subfamilies Pedinae and Pectininae (Stenzel, 1971; Hertlein and Jordan, 1927; Waller, 1969, 2011; Bouchet, 2012).

Differences in the numbers of ribs (38) in comparison with the other species such as Argopecten levicostatus are the most specific property of this species. The normal rib number in different species of Argopecten ranges from 17 to 25 (Moore, 1984; Morales-Ortega et al., 2016). 
Stratigraphic distribution of Argopecten is Oligocene to recent (Moore, 1984), except the only report from the Eocene of Bateque Formation, Baja California Sur, Mexico (Morales-Ortega et al., 2016). Our new finding from the Kopet-Dagh Basin is the second report of this genus from the Early Eocene and the first occurrence from the Tethyan realm in the Asiatic provinces; it extends its geographic distribution eastward.

\section{Subclass Heterodonta Neumayr, 1884 \\ Superfamily Carditoidea Fleming, 1828 \\ Family Cardiidae Lamarck, 1809 \\ Genus Cardium Linnaeus, 1758 \\ Cardium sp.}

Figure 6.4

Material: four cast of right valves, MASSH 0038 - MASSH 0041.

Stratigraphic occurrence in the Kopet-Dagh Basin: Chehelkaman Formation, Sheikh section, horizon 1 at $1.1 \mathrm{~m}$ from the base, horizon 2 at $9 \mathrm{~m}$ from the base.

Description. - Small size, oval-sub-triangular outline and rather inflated internal casts. Shell height is slightly greater than its length. Umbo very prominent, incurved, rounded and orthogyrated. The sculpture consists of at least 20 rounded ribs, denser in umbonal region and the interspaces widely spaced toward ventral side. Surface slightly arched between the umbos and ventral margin.

Dimensions. - L: $34 \mathrm{~mm}, \mathrm{H}: 37 \mathrm{~mm}$.

Taxonomic comments. - Although specimens are imperfect, they show some features such as outline and radial ribs, which are separated by a wide and conspicuous channeled interspace. Ribs on the middle part are flatter with interspace, wider and more channeled toward ventral side. Less compact ribs and incurved umbo are index features for Cardium halaense and Cardium kanleanum that have already been reported from Eocene sedimentary succession of Afghanistan (Berizzi Quarto di Palo, 1970).
Superfamily Cardioidea Lamarck, 1809

Superfamily Lucinacea Fleming, 1828

Family Lucinidae Fleming, 1828

Genus Pterolucina Chavan, 1942

Pterolucina sp.

Figures $6.5 \mathrm{a}-6.5 \mathrm{c}$

Material: four left valves, MASSH 0042 - MASSH 0045.

Stratigraphic occurrence in the Kopet-Dagh Basin: Chehelkaman Formation, Sheikh section, horizon 1 at $0.3 \mathrm{~m}$ from the base, horizon 2 at 1.1 $\mathrm{m}$ from the base, horizon 3 at $9 \mathrm{~m}$ from the base.

Description. - Internal bivalve cast, small in size, shell equivalve, equilateral and slightly oblique toward posterior, slightly spherical and circular in outline shape, height slightly more than width, regularly biconvex and compressed, very hollowed beneath the umbo. A type of marginal keel can be seen running from the dorsal side to ventral. Central part of the valves more convex in comparison with laterals. Ornamentation not well preserved but in some parts concentric lamella can be conspicuous. Umbos slightly prominent.

Dimensions. - L: $21 \mathrm{~mm}, \mathrm{H}: 26 \mathrm{~mm}$.

Taxonomic comments. - Maximum convexity of this species is in the mid- umbonal region and slowly decreasing toward the posterior and anterior sides. Umbo slightly recurved forwards. As a result of the poor preservation in our specimens, ornamentations are not visible. Cosel (2006) discussed that the new genus foellina (Cosel, 2006) most closely resembles Pterolucina, but Pterolucina has more separated areas and a stronger hinge dentition.

Superfamilia Veneroidea Rafinesque, 1815 Family Veneridae Rafinesque, 1815 Genus Pelecyora Dall, 1902

Subgenus Cordiopsis Cossmann, 1910

\section{Pelecyora (Cordiopsis) subathooensis d'Archaic and Haime, 1854}

Figures 6.6a, 6.6b, 6.7a and 6.7b

1975 Cordiopsis subathooensis, Mathur, figs. 4A-F 
2000 Cordiopsis subathooensis, Mathur and Juyal, Pl. 10, figs. 5-6

Material: six internal molds, MASSH 0046 MASSH 0051.

Stratigraphic occurrence in the Kopet-Dagh Basin: Chehelkaman Formation, Sheikh section, horizon 1 at $0.3 \mathrm{~m}$ from the base, horizon 2 at $9 \mathrm{~m}$ from the base.

Description.- Convex specimens with an oval outline and anteroposteriorly elongate. Umbo prominent and prosogyrated, lunule faintly marked. Commarginal growth lines weakly impressed in the surface. A narrow keel running along the margin indicates a partial opening of the valves.

Dimensions. - MASSH 0054; L: 49 mm, H: 42 mm, thickness: $25 \mathrm{~mm}$. MASSH 0055; L: $43 \mathrm{~mm}$, H: $38 \mathrm{~mm}$, thickness $19 \mathrm{~mm}$. Range: L: 27-49 mm, H: 21-42 mm, thickness: 9-25 mm. Average: L: $35 \mathrm{~mm}, \mathrm{H}: 29 \mathrm{~mm}$, thickness: $15 \mathrm{~mm}$.

Taxonomic comments. - The species shows a considerable variation in shape from ovate to bluntly trigonal, subtrapezoidal to subtrigonal (Mathur and Juyal, 2000). Pelecyora (Cordiopsis) subathooensis has a subcentral umbo that shifted anteriorly and somewhat rolled inward. Lunule not impressed but large and cordiform. The surface possesses concentric striations. The species was only recorded for the Ypresian rocks of the Indus Basin (Mathur and Juyal, 2000).

Genus Meretrix Lamarck, 1799

\section{Meretrix sp.}

Figures 6.8a and 6.8b

Material: five internal molds, MASSH 0052 MASSH 0056.

Stratigraphic occurrence in the Kopet-Dagh Basin: Chehelkaman Formation, Sheikh section, horizon 1 at $1.1 \mathrm{~m}$ from the base, horizon 2 at $9 \mathrm{~m}$ from the base.

Description. - Small size, convex and ovate, elongated anteroposteriorly. Shell equivalve but right valve slightly smaller than the left one. Umbo prominent, rounded and prosogyrated. Umbonal apex of right and left valves not in contact. Concentric growth line faintly impressed.

Dimensions. - L: 29 mm, H: 23 mm, convexity of left valve: $7 \mathrm{~mm}$.

Taxonomic comments. - The form of the shell, convexity and features of the umbo best fits with the genus Meretrix.

Order Myoida Goldfuss, 1820

Superfamily Hiatelloidea Gray, 1824

Family Hiatellidae Gray, 1824

Genus Panopea Ménard de la Groye, 1807

\section{Panopea sp.}

Figures 7.1a and 7.1b

Material: two external molds, MASSH 0057 MASSH 0059.

Stratigraphic occurrence in the Kopet-Dagh Basin: Chehelkaman Formation, Sheikh section, horizon 1 at $1.1 \mathrm{~m}$ from the base.

Description.- Shell is elongate, rather thick, large, left valve moderately convex, right valve slightly convex. Beak small, acute and wholly recurved, umbonal part is triangular. External surface is covered with fine concentric ornament. Antero-posteriorly elongated. Width of the shell greater than its height.

Dimensions. - L: $39 \mathrm{~mm}, \mathrm{H}: 27 \mathrm{~mm}$.

Taxonomic comments. - Okan and Hoşgör (2009) discussed in the Tethys provinces that most of Early Paleogene deep burrowing bivalves have been assigned to different Panopea species. The main distinguishing characters of this genus is its elongated shape and its rather short anterior margin (Okan and Hoşgör, 2009).

Subclass Anomalodesmata Dall, 1889

Order Pholadomyoida Newell, 1965

Family Pholadomyidae Gray, 1847

Genus Pholadomya Sowerby, 1823

\section{Pholadomya sp.}

Figures $7.2 \mathrm{a}$ and $7.2 \mathrm{~b}$

Material: one articulated specimen of internal mold, MASSH 0060. 


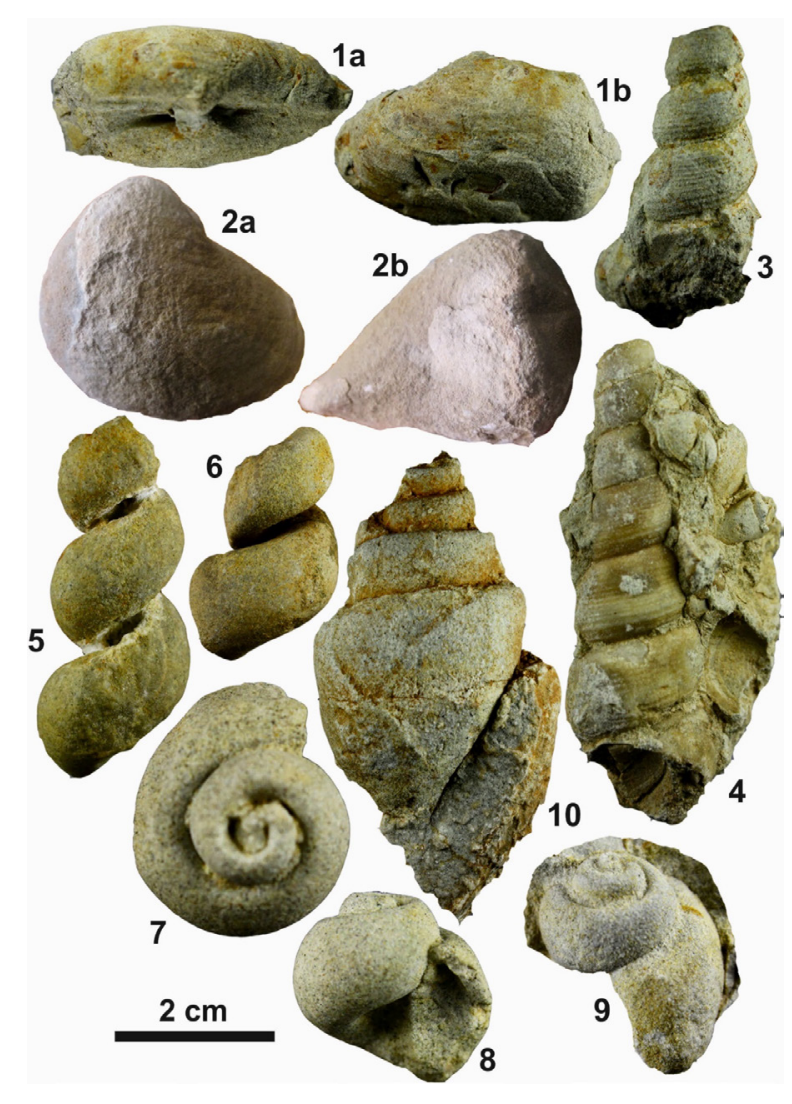

Figure 7 1a-1b: Panopea sp., \#MASSH 0058, Sheikh section; 2a-2b: Pholadomya sp., \#MASSH 0060, Sheikh section; 3: Turitella subathooensis, \#MASSH 0066, Sheikh and Ghaleh-Zou sections; 4: Haustator gilberti, \#MASSH 0094, Sheikh and Ghaleh-Zou sections; 5-6: Tenagodus sowerbyi, \#MASSH 0097 - 0098, Sheikh and Ghaleh-Zou sections; 7-9: Globularia sp., \#MASSH 0100 - 0102 , Sheikh section; 10: Turbinella bulbiformis, \#MASSH 0111 , Sheikh section.

Stratigraphic occurrence in the Kopet-Dagh Basin: Chehelkaman Formation, Sheikh section, horizon 1 at $0.3 \mathrm{~m}$ from the base.

Description. - The external shell is missing however the internal mold exhibits sufficient morphological features to identify at generic level. Large dimensions, inequilateral, ovate globose, oblong in outline. Umbo prominent and ornamentations consist of many thin ribs. Anterior portion reduced and posterior portion elongated. Strongly inflated.

Dimensions. - L: $55 \mathrm{~mm}, \mathrm{H}: 47 \mathrm{~mm}$, inflation: 37 $\mathrm{mm}$.

Taxonomic comments. - Prominent features for identification of this specimen are the outline, inequilateral, strongly inflated and reduced anterior portion that is in contrast to the elongated posterior portion (Harzhauser and Mandic, 2001).
Class Gastropoda Cuvier, 1795

Superfamily Cerithioidea Ferrusac, 1819

Family Turritellidae Lovén, 1847

Genus Turritella Lamarck, 1799

Turritella subathooensis d'Archaic and Haime, 1854

Figure 7.3

2000 Turritella subathooensis, Mathur and Juyal, Pl. 11, figs. 4-12

Material: thirty one specimens, MASSH 0061 - MASSH 0091.

Stratigraphic occurrence in the Kopet-Dagh Basin: Chehelkaman Formation, Sheikh section, horizon 1 at $0.3 \mathrm{~m}$ from the base, horizon 2 at 1.1 $\mathrm{m}$ from the base, horizon 3 at $9 \mathrm{~m}$ from the base. Ghaleh-Zou section, horizon 1 at $4.3 \mathrm{~m}$ from the base, horizon 2 at $4.59 \mathrm{~m}$ from the base. 
Description.- Medium to large, turriculate to conical, and high-spired gastropods. Spire elongated, consisting of about 4 non-overlapping whorls (incomplete specimen), separated by slightly deep sutures. Whorl surfaces gently convex, each whorl ornamented with about 15-17 tuberculate thin spiral cords. Protoconch and fist whorls not preserved. Diameter of whorls increasing gradually from apex to aperture.

Dimensions. - H: $35 \mathrm{~mm}$ (incomplete), W: $15 \mathrm{~mm}$. Taxonomic comments. - This species is only recorded in the Ypresian sediments of Indus Basin, characterized by turreted, gently convex whorls, rather loosely coiled and body whorl ornamented by concentric oblique growth lines (Mathur and Juyal, 2000). Preservation of the specimens described here is better than the Indus region forms.

Genus Haustator Montfort, 1810

\section{Haustator gilberti Bowles 1939}

Figure 7.4

1939 Turritella gilberti, Bowles, Pl. 32, fig. 16

1996 Turritella gilberti, Allmon, Pl. 7, figs. 4-5

1969 Turritella gilberti, Toulmin, Pl. 2, fig. 10

1980 Turritella gilberti, Dockery, Pl. 2, fig. 2

Material: four specimens, MASSH 0092 - MASSH 0095.

Stratigraphic occurrence in the Kopet-Dagh Basin: Chehelkaman Formation, Sheikh section, horizon 1 at $0.3 \mathrm{~m}$ from the base. Ghaleh-Zou section, horizon 1 at $4.3 \mathrm{~m}$ from the base, horizon 2 at $4.59 \mathrm{~m}$ from the base.

Description. - Shell medium to large, fairly thin walled, slenderly turriculate to conical, and highspired. Spire elongated and consisting of about 7 non-overlapping whorls (incomplete specimen), separated by moderately deep sutures. Whorl slightly convex to flat and closely spaced spiral threads on rounded to basally carinate. Protoconch and fist whorls not preserved; growth lines conspicuous. Each whorl ornamented with about 12 to 14 tuberculate thin spiral cords. Diameter of whorls increasing gradually from apex to aperture. Dimensions. - H: $53 \mathrm{~mm}$ (incomplete), W: $15 \mathrm{~mm}$.
Taxonomic comments. - Shape of adult whorl and occurrence of basal carinate in Haustator is a prominent feature in the Paleocene and lower Eocene turritellid assemblages (Allmon, 1996; Gale et al., 1999).

Family Siliquariidae Anton, 1838

Genus Tenagodus Guettard, 1770

Tenagodus sowerbyi Halder and Sinha, 2014

Figures 7.5 and 7.6

2014 Tenagodus sowerbyi, Halder and Sinha, figs. $3 \mathrm{~s}-3 \mathrm{u}$

Material: three specimens, MASSH 0096 MASSH 0098.

Stratigraphic occurrence in the Kopet-Dagh Basin: Chehelkaman Formation, Sheikh section, horizon 1 at $0.3 \mathrm{~m}$ from the base.

Description.- Medium to large, turriculate to conical and high-spired shell. Spire elongated consists of about 2 to 4 non-overlapping tube like whorls (incomplete specimens), with loose coiling separated by strongly and spaced deep sutures. Whorl surfaces strongly convex, Protoconch and first whorls not preserved. Diameter of whorls increasing gradually from apex to aperture.

Dimensions.- H: $41 \mathrm{~mm}$ (incomplete), W: 15 $\mathrm{mm}$.

Taxonomic comments. - Strongly and spaced deep sutures, loose whorls and absence of carina separated this specimen with Turitella. This species is similar to the specimens from the Kutch district of India reported for first time by Halder and Sinha (2014).

Superfamily Ampullinoidea Cossmann 1918

Family Ampullinidae Cossman, 1918

Genus Globularia Swainson, 1840

Globularia sp.

Figures $7.7-7.9$

Material: twelve specimens, MASSH 0099 MASSH 0110. 
Stratigraphic occurrence in the Kopet-Dagh Basin: Chehelkaman Formation, Sheikh section, horizon 1 at $0.3 \mathrm{~m}$ from the base, horizon 2 at $1.1 \mathrm{~m}$ from the base, horizon 3 at $10.6 \mathrm{~m}$ from the base.

Description.- Shell globose, small to large, lowspired with overlapping whorls that are slightly convex and separated with deep sutures; 4 to 6 whorls that rapidly decrease toward the apex. Greatly inflated body whorl and large aperture. Dimensions. - H (range): 25 - $35 \mathrm{~mm}, \mathrm{~W}$ (range): $17-23 \mathrm{~mm}$.

Taxonomic comments. - Globularia has a large last whorl and low spire. A lot of species for this genus have been reported from Paleocene and Eocene deposits of Tethys realm. Their stratigraphic occurrence in the Kopet-Dagh Basin is similar to the same occurrence in Turkey (see: Okan and Hoşgör, 2008).

\author{
Clade Neogastropoda \\ Superfamily Muricoidea Rafinesque, 1815 \\ Family Turbinellidae Swainson, 1835 \\ Genus Turbinella Lamarck, 1799
}

Turbinella sp.

Figure 7.10

Material: one specimen, MASSH 0111.

Stratigraphic occurrence in the Kopet-Dagh Basin: Chehelkaman Formation, Sheikh section, horizon 1 at $0.3 \mathrm{~m}$ from the base.

Description: Very thick, large and high spire shell with a body whorl quickly increasing in size in comparison with the primary whorls. Aperture linear and narrower oval.

Dimensions.- H: $81 \mathrm{~mm}, \mathrm{~W}: 41 \mathrm{~mm}$.

Taxonomic comments. - From the viewpoint of Davies (1935) and Squires (2012) distinguishing characters of Turbinella are a pyriform shell, ornament of spiral ribs and weak nodes on the last whorl, oval aperture and outer lip internally smooth. Although the specimens in this study are generally internal molds, they show all the typical features of Turbinella as can be seen in Kachhara et al. (2011).

\section{Faunal features of the shell beds}

A sensu lato shell bed is considered here as any horizontal and continuous bed with high concentrations of mollusk fossils including shells, molds or casts (Dorsey and Kidwell, 1999). By this definition, four shell beds are recognized in the Sheikh section, and only one in the Ghaleh-Zou section. They are described as follow and named based on the most abundant macrofossil contents.

\subsection{SHEIKH SEGTION}

\subsubsection{TURRITELLIDAE SHELL BED}

This shell bed is located at $+0.3 \mathrm{~m}$ from the base of the section (Figure 2), with 0.3 to $0.4 \mathrm{~m}$ thick. The bed consists of high-spired shells in a silty, moderately sorted, fine-grained and poorly cemented sandstone matrix. In this bed, fossils belong to two classes of mollusks. Bivalves are represented by shells of Pycnodonte sp., Pelecyora (Cordiopsis) subtahooensis, Cardium sp., and Pholadomya sp. representing about twenty-five percent prequency of collected fossils from this bed. Gastropods are

Table 1. Relative abundance of macrofossil groups from the Sheikh section in the Turritelline horizon.

\section{Groups $\quad$ Percentages}

Turritelline gastropod fauna

68.86

Non Turritelline gastropod fauna

5.13

Oyster fauna

15.03

Other bivalves

10.98

signified by shells of Globularia sp. and Turritellidae with the latter the most abundant mollusk taxa (Table 1) in the beds, which includes the species Turritella subathooensis, Haustator gilberti, and Tenagodus sowerbyi in a very high relative percentage.

Rare gastropods (almost 5\%) and some bivalves (nearly $30 \%$ ) preserve the shell. The remainder fossils consist of sandy cemented shels of both internal and external cast. Based on some biostratinomic data, such as degree of disarticulation and corrosion, fragmentation of fragile and robust fossils and bioerosion of skeletal elements (shown in 
Table 2. Susceptibility of invertebrate fossil skeleton to various biostratinomic processes in the studied sections.

\begin{tabular}{|c|c|c|c|c|c|c|}
\hline Skeletal type & Intact transport & Fragmentation & Disarticulation & Corrosion & Encrustation & Boring predation \\
\hline Gastropod fauna & + & + & - & + & + & Absent \\
Oyster fauna & + & + & \pm & + & + & + \\
Other bivalves & + & + & \pm & + & Absent & Absent
\end{tabular}

the Table 2), perspective of fossil preservation was provided for the studied sections. More than half of the bivalve and gastropod shells and their casts represent fragmentation and almost half of them show fracturing. However, almost all of them are disarticulated. The external surface of the shell is moderately to strongly abraded, but there are no signs of encrustation, bioerosion, and predation.

The shell size of turritellids ranges between 2 and $6 \mathrm{~cm}$, which represent the different stages of their growth. The presence of different shell sizes indicates a weak sorting. The gastropods have a bimodal orientation (Figure 8) as turritelline shells are commonly oriented along their axis, which indicates effects of oscillatory waves (e.g., Seilacher, 1959, 1973; Fürsich and Oschmann, 1993) rather than unidirectional currents.

\subsubsection{PYCNODONTE - TURKOSTREA SHELL BED}

The lower basement of this shell bed is located at $+1.1 \mathrm{~m}$ from the base of the section. The bed has a thickness of $2 \mathrm{~m}$ and the interval between two con- secutive shell beds is unfossiliferous. The matrix is composed of fine-grained muddy sandstone. Two subtypes are recognized, including moderately sorted with edgewise-oriented bioclasts (Figure 6b). Toward the top bed, the matrix changes to a well sorted with random to convex up oriented bioclasts (Figures 9b and 9c). The bivalves consist of Pycnodonte sp., Ostrea (Turkostrea) afghanica, Ostrea (Turkostrea) turkestanensis, Argopecten sp., Cardium sp., and Pholadomya sp. The gastropods contain a small amount of turritelline and Globularia sp. The most abundant group is the oysters, showing a relative $80 \%$ frequency. Toward the upper part of the bed, fossil content strongly increases. The best-preserved fossils are oysters and Argopecten sp., while Cardium sp., and Pholadomya sp. consist of internal or external molds.

All shells are moderately fragmented (Figures 9 and 10), and shell fragments were observed floating in the calcareous matrix toward the bed top, with a sparse packing (Figure 9). Almost all oyster shells are disarticulated, predominating left valves

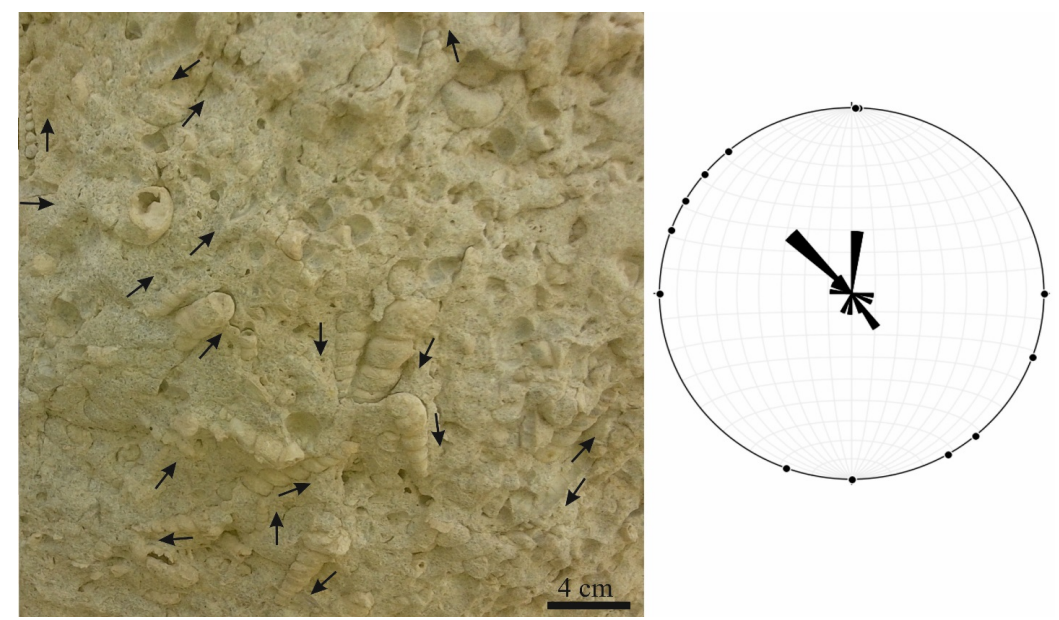

Figure 8 Turritellidae shell bed in the Sheikh section contains high spired gastropods; the rose diagram was drawn based on the measurement of 18 specimens orientations within the bed, which confirms the bimodal alignment along their axis due to the oscillatory waves. 


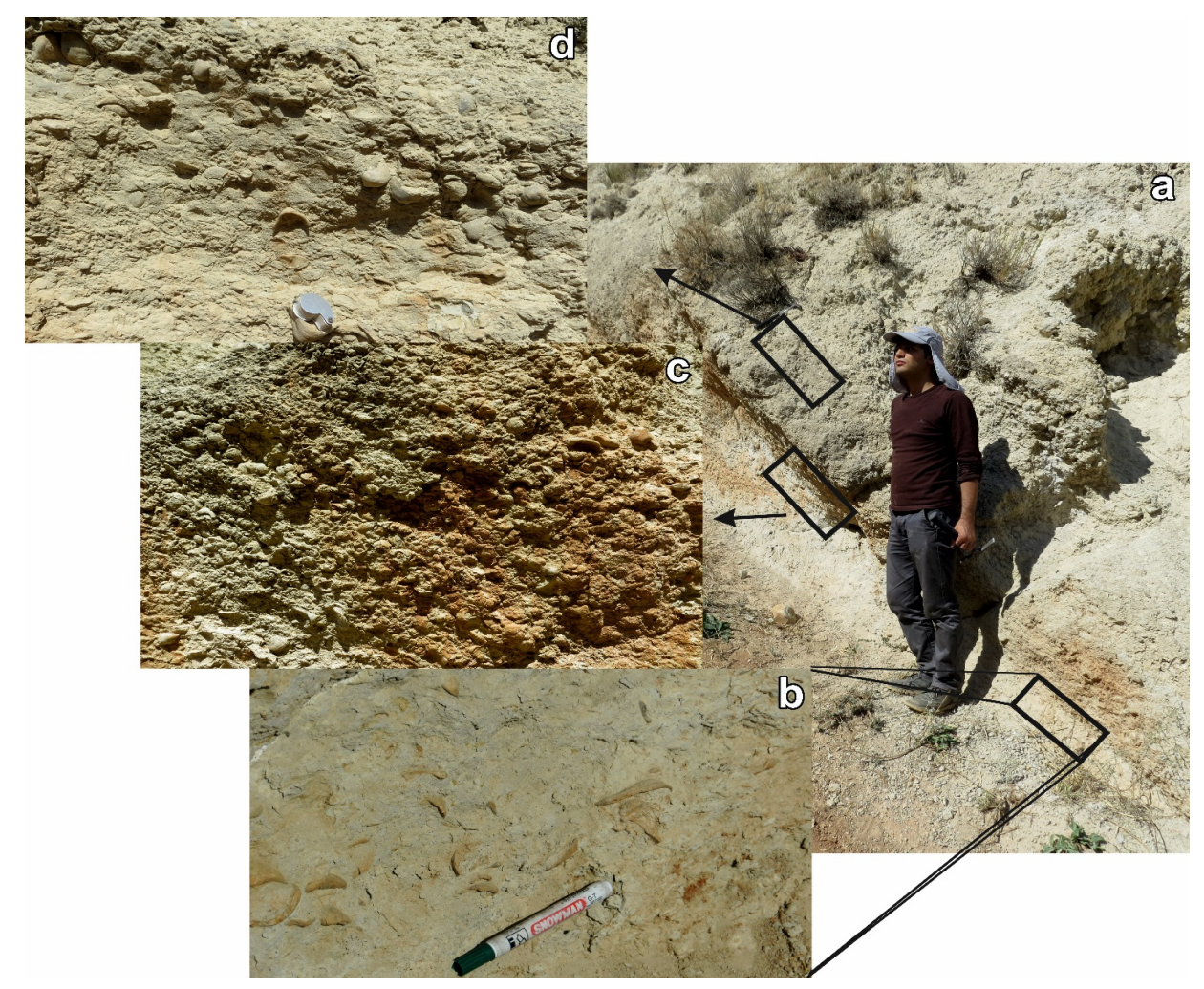

Figure 9 a: Pycnodonte - Turkostrea shell bed, b: fragmentation of the shells, indicator of high energy conditions in the environment; c-d: disarticulated shells, left valve dominant and convex up oriented bioclasts; display high energy and stormy conditions in the environment.

$(90 \%)$. Their elements almost situated in inverse life position (convex-upward) and their left valves are strongly encrusted and bored (Figures 9c, 9d and 10). Attachment areas of the most presence oysters are small.

\subsubsection{PELECYORA (CORDIOPSIS) SUBATHOOENSIS - CARDIUM SHELL BED}

This shell bed with the thickness of 0.4-meter thickness is located at $+9 \mathrm{~m}$ from the base of the section and the barren distance between the second and third shell bed. The matrix is composed of calcareous siltstone. Collected taxa are represented by the bivalves Pycnodonte sp., Cardium sp., Pelecyora (Cordiopsis) subathooensis, and the gastropod Turritella subathooensis. The dominant fossils belong to Pelecyora (Cordiopsis) subathooensis and Cardium sp. that is relatively high in abundance. Most bivalves are articulated. The remaining specimens are casts derived from articulated valves. The only recognized taphonomic feature is a moderate fragmentation in the shells and casts.

The specimens do not exhibit a particular trend in arrangement or orientation. All shells show a random convex up or down arrangement of the shells. Except by the Pelecyora (Cordiopsis) subathooensis, being all in situ life position (Figures $11 \mathrm{a}-11 \mathrm{~d})$. The fossil density in the shell bed is especially higher in Cordiopsis - Cardium horizons, which represent a pavement structure in the Cordiopsis - Cardium shell bed (Figure 11).

\subsubsection{GLOBULARIA SP. SHELL BED}

The shell bed with 0.5-meter thickness is located at $+10.6 \mathrm{~m}$ distance from the base of the section, with a matrix composed of silty marl. Most of fossils are internal molds of gastropods. The 


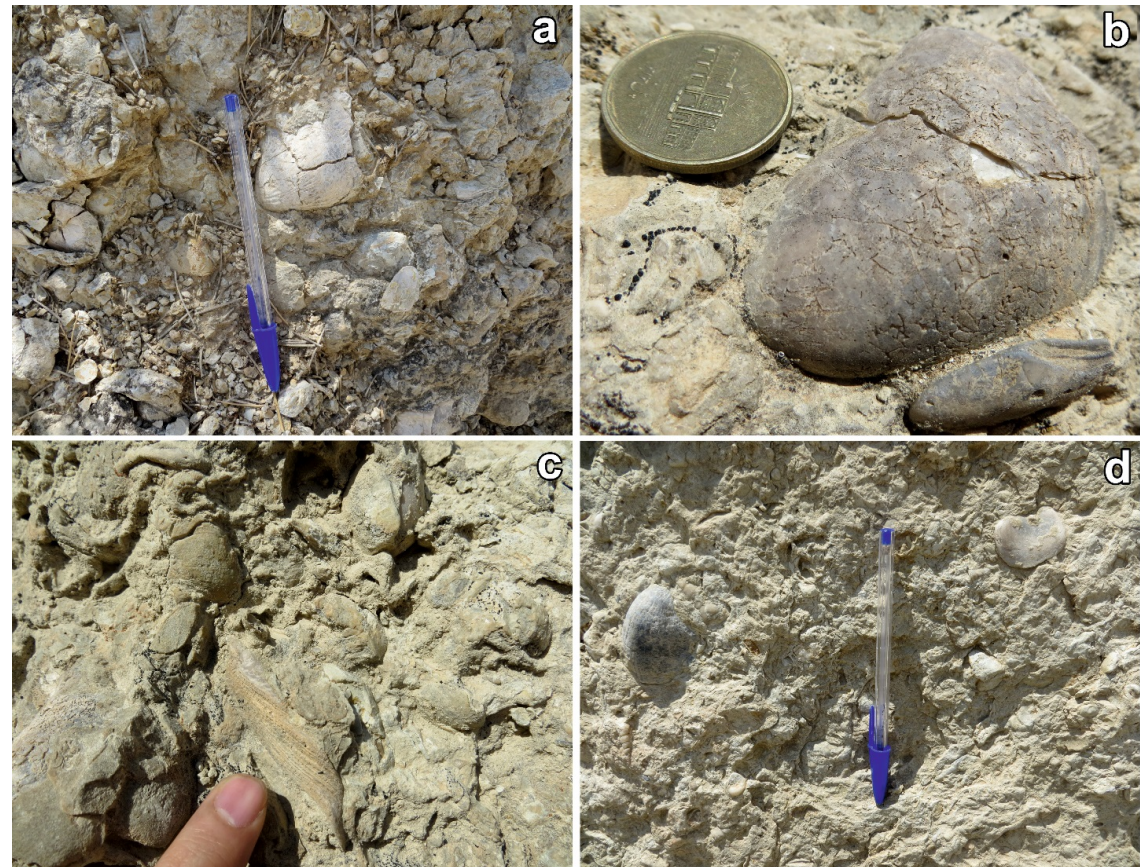

Figure 10 Fragmentation in Pycnodonte - Turkostrea shell bed; b: strongly encrustation and bored on the left valves of oysters in Pycnodonte - Turkostrea shell bed.

fossils of Ampullinidae shells, Globularia sp., are the only element with moderate frequency with preserved shell and remnants of internal casts. The shells are rarely broken. The only recognized taphonomic event is moderate encrustation marks on the shells and casts aperture area with no signs of fragmentation.

\subsection{GHALEH-ZOU SEGTION}

\subsubsection{TURRITELLIDAE SHELL BEDS}

In the Ghaleh-Zou section, there is a couple of shell beds in the distance of 4.3 and $4.6 \mathrm{~m}$ from the base of the section (Figure 3a), separated from each other by a cross-stratified sandstone. The thickness of the lower bed is $0.15 \mathrm{~m}$ and the upper is $0.12 \mathrm{~m}$. The matrix in both beds is composed of white loose sand in non-weathered surfaces and buff in weathered surfaces. The only macrofossil contents of both shell beds are turretellids, such as Turritella sp. and Haustator sp. They do not have preserved shells, but rather consist of almost entirely fragmented, incomplete specimens with a random and irregular arrangement (Figures 12b - 12e).

\section{Age dating}

The assemblage of Pelecyora (Cordiopsis) subathooensis and Turritella subathooensis in two shell beds of the Sheikh section, and the Turritellidae shell bed and Pelecyora (Cordiopsis) subathooensis - Cardium shell bed, allows us to assign them to the Cordiopsis subathooensis - Turritella subathooensis Zone, established by Mathur and Juyal (2000) from the Subathu area of India. This biozone is equivalent to the middle parts of the planktonic foraminifera P8 Zone (Berggren et al., 1995). Therefore the association at the Sheikh section indicates an early Eocene age. Sahni and Kumar (1983) in the Lesser Himalaya, Northwestern India, reported several bivalve and gastropod genera such as Venericardia, Trachycardium, Seila, Venus, Pinna, and some species of turritellids as associate fauna with the Pelecyora (Cordiopsis) subathooensis - Turritella subathooensis Zone. In the Sheikh section, associate macrofossils in this zone are oysters and Cardium sp.

To verify of an early Eocene age for the Chehelkaman Formation at the Sheikh section, 10 samples were prepared for nannofossils investigations. 

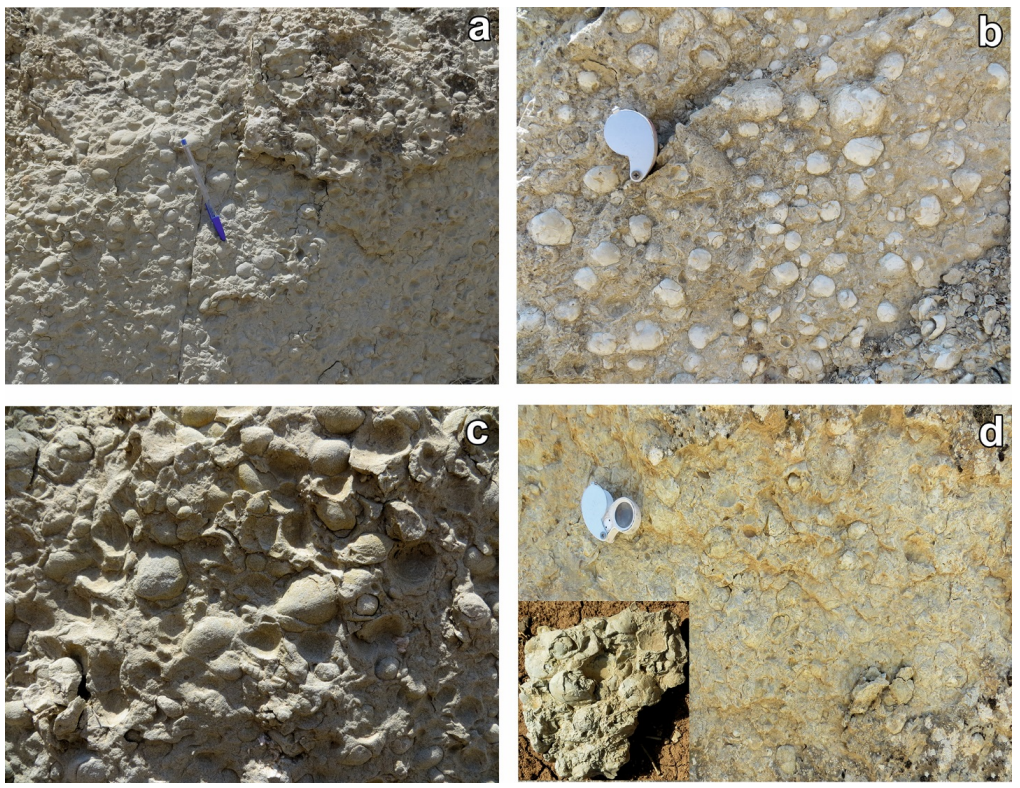

Figure 11 Thin pavements of Cordiopsis - Cardium shell bed in Sheikh section. They indicate comparatively motionless environment after a storm (a-d).

These samples were taken from thin muddy lamina and calcareous parts of the formation. Based on the extracted nannofossils (Figure 14) the biozones NP12 and lower part of NP13 were recognized in this section, which concur with the ages of the macrofossil assemblages. The documented nannofossils zones are as follow:

\subsection{TRIBRAGHIATUS ORTHOSTYLUS ZONE (NP12)}

According to Perch-Nielson (1985) this biozone comprises the interval from the first occurrence of Discoaster lodoensis to the last occurrence of Tribrachiatus orthostylus or the first occurrence of Toweius crassus. This biozone, which is equivalent to $\mathrm{CP} 10$ of Okada \& Bukry (1980), corresponds to the lower $8 \mathrm{~m}$ rocks of the Chehelkaman section. The most important associate nannofossils of this biozone are Chiasmolithus consuetus, Chiphragmalithus armatus, Coccolithus pelagicus, Discoaster barbadiensis, Discoaster diastypus, Discoaster lodoensis, Discoaster rkuepperi, Ellipsolithus macellus, Ericsonia formosa, Helicosphaera lophota, Markaliu sinversus, Neococcolithes dubius, Neococcolithes protenus, Reticulofenestra dictyoda, Sphenolithus conspicus, Sphenolithus editus, Sphenolithus moriformis, Sphenolithus radians, Tribrachiatus orthostylus, and Zygrhablithus bijugatus.

\subsection{DISCOASTER LODOENSIS GONGURRENT RANGE ZONE (NP13)}

The lower boundary, defined above, coincides with the upper boundary markers of NP12. Its upper boundary characterized by the first occurrence of Discoaster sublodoensis (Perch-Nielson, 1985), is equivalent to CP11 of Okada \& Bukry (1980). This interval zone includes the succession from +8 $m$ from the base of the Chehelkaman Formation into $2 \mathrm{~m}$ within the Khangiran Formation. Due to the absence of Discoaster sublodoensis in the studied sections last occurrence of Toweius crassus is used as the upper zonal marker (Perch-Nielson, 1985). Other nannofossil associations within this biozone are Chiasmolithus consuetus, Coccolithus pelagicus, Discoaster deflandrei, Discoaster kuepperi, Discoaster lodoensis, Ericsonia formosa, Helicosphaera lophota, Reticulofenestra dictyoda, Sphenolithus moriformis, and Toweius crassus.

\section{Discussion}

\subsection{PALEOEGOLOGICAL GONDITIONS}

Shell beds are skeletal concentrations taphocenosis, common features of shelf environments in the 


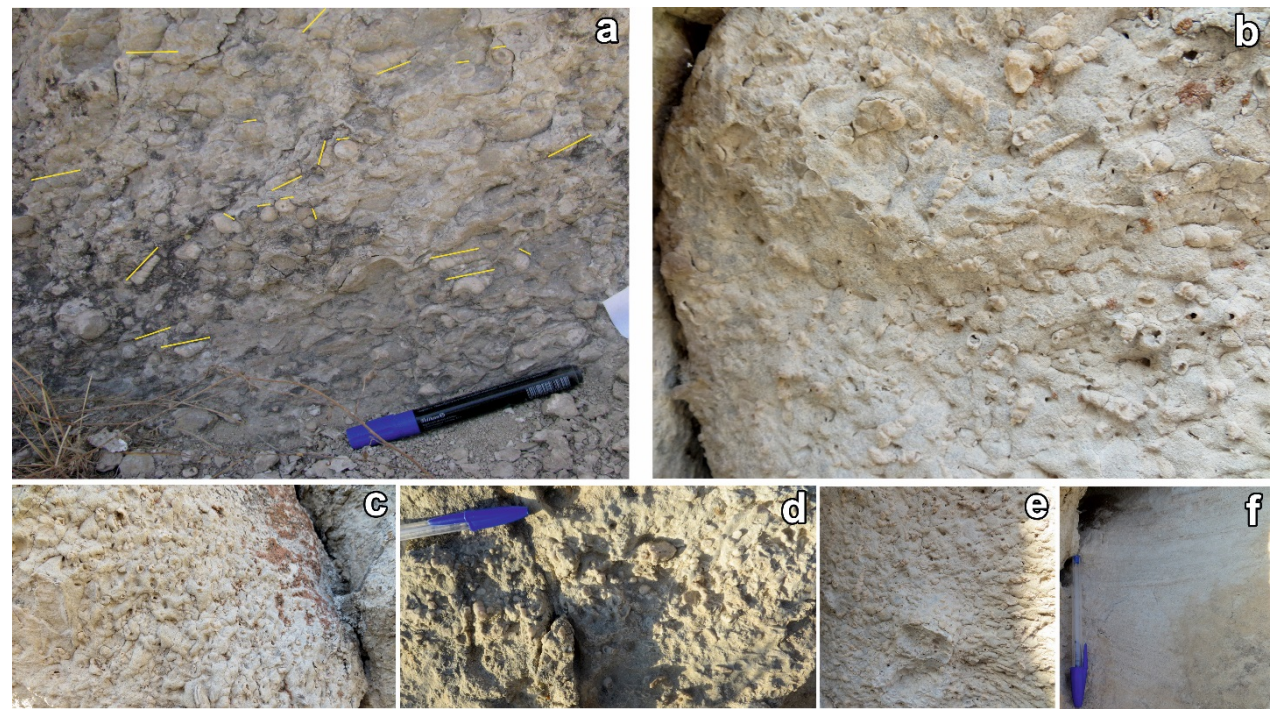

Turriteline shell bed in the Sheikh section (a) and Ghaleh-Zou section (b-f).

past and present (Kidwell et al., 1986). They are important tools to retrieve fossil taxa, and have been extensively considered for paleoecological analysis (e.g., Muller, 1951; Schafer, 1972; Brett and Baird, 1986; Fürsich and Oschmann, 1993; Fürsich and Pandey, 1999). The shell beds work as environmental indicators and useful records for both ecological interpretations and recognition of the processes related to the formation of layers (Kidwell et al., 1986; Gordillo et al., 2014).

The turritellid shell bed at the SSA is characterized by a high abundance of elements, but with a low diversity, less than 10 genera or 10 species. This shell bed matches well with the Turritelline Dominated Assemblage (TDA) described by Allmon and Knight (1993); however they reported them from the Cretaceous succession. TDAs are dense macrofossil assemblages, dominated by turritellids in a low total diversity ( $<20$ species). The TDAs are associated to sandstone and limestone rocks, being a widespread geological phenomenon from Cretaceous through Cenozoic (Allmon and Knight, 1993). According to Allmon (1988), communities with high abundance of turritellids required a nutrient enriched environment. Some other studies on the turritellid populations have revealed a correlation among high levels of nutrients, high productivity, and high abundance of these gas- tropods (Allmon et al., 1992, 1994, 2011). Hence, an important factor in the formation of TDAs is a high biological productivity due to nutrient accretion, which is associated with runoff, volcanism or upwelling (Allmon, 1988, 2007).

The TDA of the Sheikh section therefore may indicate a nutrient enrich environment in the basin during an early moment just after the Cenozoic transgression (Figure 2). Volcanic activities have never been reported from the Kopet-Dagh Basin (Afshar-Harb, 1979) and coastal upwellings are ignored due to the absence of evidences, but a significant input of nutrients from continent might have enriched the marine basin. During the Early Eocene, the high levels of carbon dioxide in the atmosphere increased the weathering of rocks (Leckie, 1989; Ravizza et al., 2001); and hot and humid conditions, accelerated the global hydrologic cycle (Schroeder, 1992; Berner, 1994; Dickens et al., 1995, 1997; Ravizza et al., 2001). Both conditions favored the entrance of continental runoff into the basin (Leckie, 1989; Ravizza et al., 2001).

The enriched basin by runoff is also suggested by the Pycnodonte - Turkostrea shell beds. The habitat, life position and feeding mechanisms of both oysters groups (gryphaeids and ostreids) found in the basins connected to a well supply of sediments and 


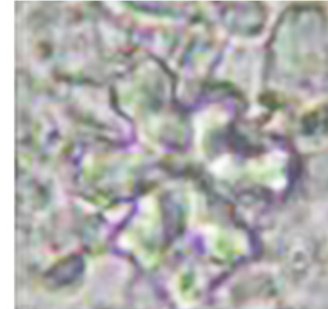

1

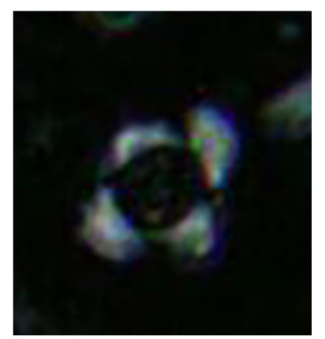

6

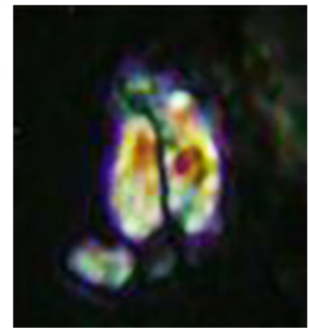

11

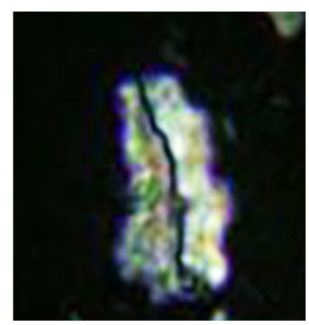

16

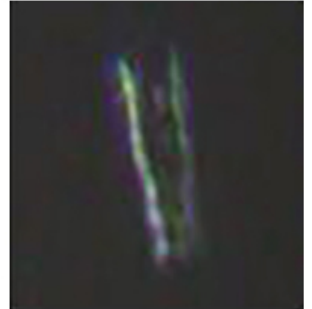

2

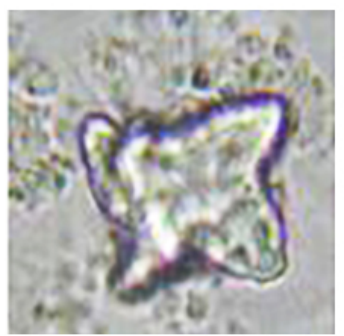

7

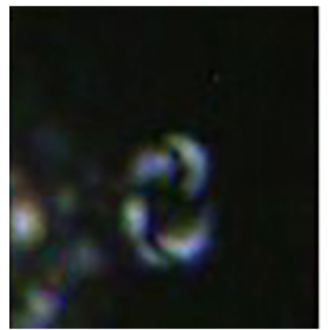

12

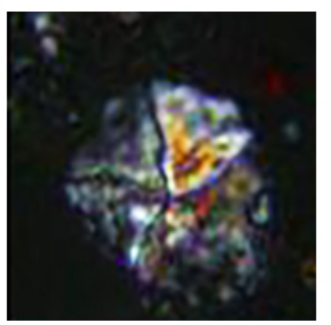

17

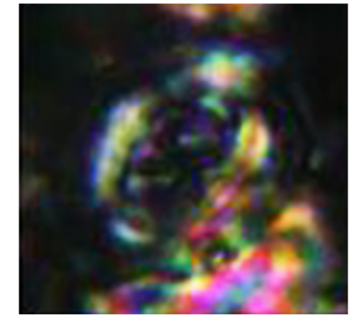

3

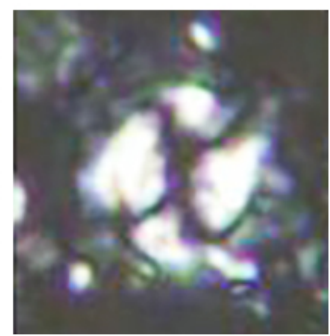

8

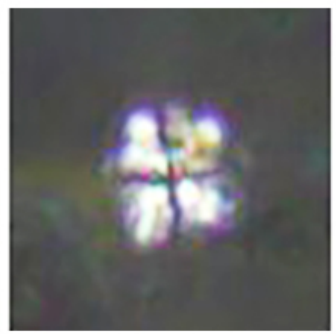

13

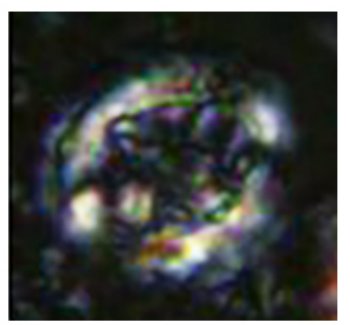

18

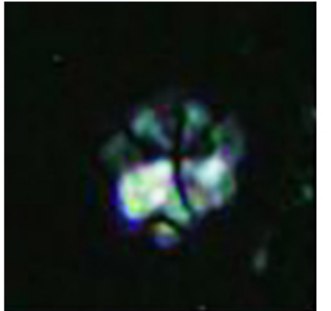

4

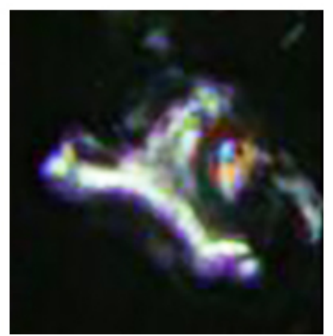

9

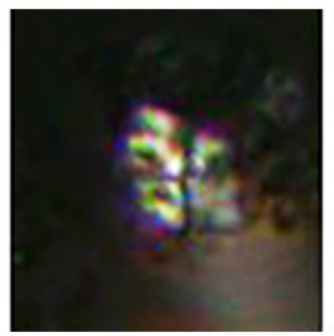

14

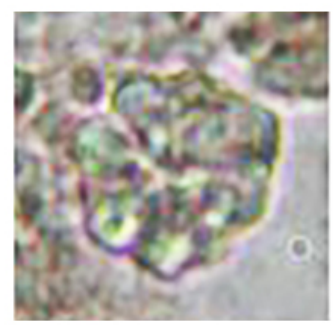

19

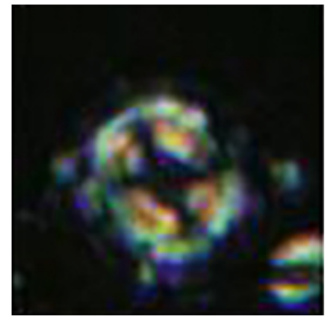

5

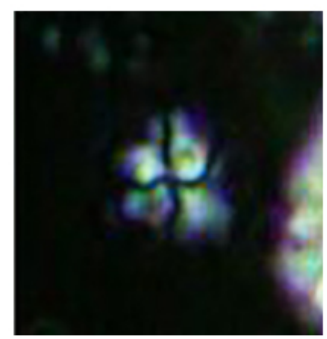

10

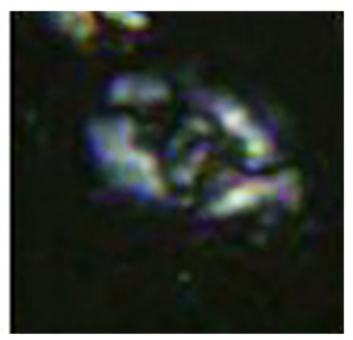

15

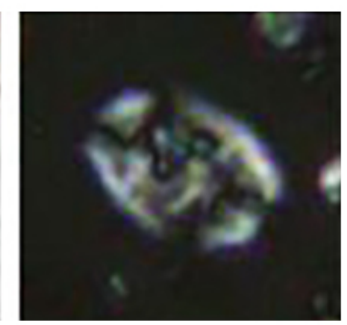

20

Figure 13 1: Discoaster deflandrei Bramlette \& Riedel, 1954; 2: Blackites spinosus (Deflandrae \& Fert, 1954) Hay \& Towe, 1962; 3: Chiasmolithus consuetus (Bramlette \& Sullivan, 1961) Hay \& Mohler, 1967; 4: Sphenolithus primus Perch-Nielsen 1971; 5: Ericsonia Formosa (Kamptner, 1963) Haq, 1971; 6: Reticulofenestra dictyoda (Deflandre in Deflandre \& Fert, 1954) Stradner in Stradner \& Edwards, 1968; 7: Tribrachiatus bramlettei (Bronnimann \& Stradner, 1960) Proto Decima et al., 1975; 8: Coccolithus pelagicus (Wallich, 1877) Schiller (1930); 9: Tribrachiatus orthostylus Shamrai, 1963; 10: Sphenolithus conspicuous Martini, 1976; 11: Fasciculithus tympaniformis Hay \& Mohler in Hay et al., 1967; 12: Toweius crassus (Bramlette \& Sullivan, 1961) Perch-Nielsen, 1984; 13: Sphenolithus moriformis (Bronnimann \& Stradner, 1960) Bramlette \& Wilcoxon, 1967; 14: Sphenolithus editus Perch-Nielsen in Perch-Nielsen et al., 1978; 15 : Helicosphaera lophota (Bramlette \& Sullivan, 1961) Locker, 1973; 16: Zygrhablithus bijugatus (Deflandre in Deflandre and Fert, 1954) Deflandre, 1959; 17: Braarudosphaera bigelowii (Gran \& Braarud, 1935) Deflandrae, 1947; 18: Chiasmolithus bidens (Bramlette \& Sullivan, 1961) Hay \& Mohler, 1967; 19: Discoaster kuepperi Stradner, 1959; 20: Ellipsolithus macellus (Bramlette \& Sullivan, 1961 ) Sullivan, 1964. (All figures in XPL except figures 1, 7 and 19 in PPL, Light micrographs $\times 1000$; scale bar for all images is are the same as fig. 1; the taxa considered in the present figure are referenced in Perch-Nielsen, 1985). 
nutrients. Most of the Cenozoic oysters live in tropical and subtropical shallow marine basins, being epifaunal organisms, living reclined or cemented, and being efficient suspension feeders (Stanley, 1970; Stenzel, 1971; Seilacher, 1984). The high boring and encrusting evidences on the fossils from the Pycnodonte - Turkostrea shell beds display the nutrient enriched environment. High levels of nutrients favored the growth of different mollusk populations and consequently increased the bioerosion of shells yielded by bivalve (e.g., encrusting) and gastropods (e.g., drilling) (Wood, 1993; Lescinsky et al., 2002).

Recent oysters occupy the intertidal zone to a water depth of $30 \mathrm{~m}$. Occurrence of Turkostrea shell beds belong to intertidal zone. Pycnodonte spp. inhabit at the subtidal zone to the depth of $30 \mathrm{~m}$. The bivalves Cardium sp., Meretrix sp., Pholadomya sp., and Panopea sp. occupy both inter and subtidal environments (Lan, 1997). Furthermore, the stout gastropod Turbinella sp. were reported from the depth range of 30 to $50 \mathrm{~m}$ (Kachhara et al., 2011), and turritellids are known from less than 2 to more than 150 m depth (Gekker et al., 1962; Stanley, 1970, 1971; Houbrick, 1992; Allmon et al., 1995; Lan, 1997; Kachhara et al., 2011).

Since turritelliidsas represent communities needing nutrients and they are the only predominant fossils in the Ghaleh-Zou section therefore we suggest a very shallow environment for this section. It is possibly related to the areas connected to the entrance of runoff from the land surface of terrestrial regimes. Lithofacies features such as loose white sandstones and fine gypsum beds confirm the depth range of this section was lesser than the Sheikh section.

\subsection{DEPOSITIONAL GONDITIONS}

\subsubsection{SHEIKH SECTION}

The dominant supply of siliciclastic sediments retain low levels of $\mathrm{CaCO} 3$, favoring the shell dissolution of several gastropods and bivalves, yielding cemented casts. Physical reworking and transportation of skeletal elements play an important role in the concentrations of the shells in the Chehelkaman Formation. This case indicates high energy levels in this phase. As well, highly encrusted and bored shells point to a long residence time on the seafloor that correspond to low rates of sedimentation. Abrasion degree, breakage and fragmentation of turritellids, their bimodal orientations and the lithofacies demonstrate the TDAs, in both Sheikh and Ghaleh-Zou sections, have deposited in the tidally dominated paleoenvironment. The same conditions were proposed for identical succession in the Caribbean province by Kirkland et al. (1996).

The bimodal orientations of turritellids along their axis (Figures 8 and 12a) indicate the effect of regular oscillatory flows (e.g., Seilacher, 1959, 1973) in the Sheikh section (Figures 8 and 12a). In contrast, turbulent flows made irregular replacement of skeletal elements in the Ghaleh-Zou section, which has led to fractures and destroyed elements within the shell beds (Figures 12b - 12d). These geometric and biostratinomic features represent concentrations under the influence of fair-weather waves, where abrasion and breakage should have been salient features (Fürsich and Oschmann, 1993).

The Pycnodonte-Turkostrea shell bed was deposited in the intertidal zone and laterally shows more turbulent conditions, around normal storm wave base. Disarticulated, shell valves - oriented convex-up valves indicate storm-flow conditions (Tomašových, 2006). Likewise a predominance of heavy and thick left valves clearly indicates sorting and influence of currents in storm flows. This high accumulation of the shells was the result of a high productivity combined with the low rates of sedimentation and occasional winnowing. The thinner right valves might have been selectively removed during winnowing, but they also could have been destroyed via bioerosion, as most shells are moderately encrusted or bored.

The degree of disarticulation, fragmentation and abrasion in bivalves suggests a low to intermediate sedimentation rate from 1 to $10 \mathrm{~cm} 10-3 \mathrm{y}$ (Brett and Baird, 1986). Notwithstanding, the thick and heavy left valves of oysters, less prone 
to transported concave down shells (Figures 9c - 9d, 10a, 10b and 10d), suggest rapid current flows (Kerans et al., 1994). Also, the absence of thin light right valves suggests a moderate energetic regime (Stenzel, 1971; Brett and Baird, 1986). Except for a few rare cases, almost all small attachment areas in oysters suggest they cemented in the mode of life only during the juvenile stage (Fürsich and Pandey, 1999).

There are not any traces of bioerosion and encrustation in the Pelecyora (Cordiopsis) subathooensis - Cardium shell bed and most of the shells are articulated. Tomašových (2006) have attributed the settling preference of such shell beds to a low energy environment, low rates of sedimentation and high frequency of dead bivalve shells. These conditions suggest a comparatively motionless environment after a storm, which produce a pavement arrangement of the shells (Figure 11).

Lithostratigraphically, the Globularia sp. shell bed is mostly marly and the rate of sandy-silty grains decreases to the topmost bed. Lack of breaking, fragmentation and a little evidence of encrustation even within the muddy matrix suggests deeper settling conditions below the influence of storm activity (Bressan and Palma, 2010).

\subsubsection{GHALEH-ZOU SECTION}

Laterally facies changes, from WNW to ESE in the SSA, have triggered differences in marine sequence from the Sheikh section into the Ghaleh-Zou section. Lithological similarity of the Pesteligh and Chehelkaman formations in the later section represent more consistent depositional conditions. The occurrences of two successive turritellid shell beds with intercalations of gypsum appear to directly indicate a shallow environment condition than the Sheikh section (Figure 10). Disturbed and irregular orientation of the suspension feeder turritelline gastropods indicates their development coincides with the energetic and turbulent stages of the rich nutrient environment (Figures 12b - 12e).

\section{Conclusion}

Clastic facies of Chehelkaman Formation in the northeast Iran at the Kopet-Dagh Basin consist of multiple molluscan assemblages in some shell beds. Paleontological investigations on these fos-

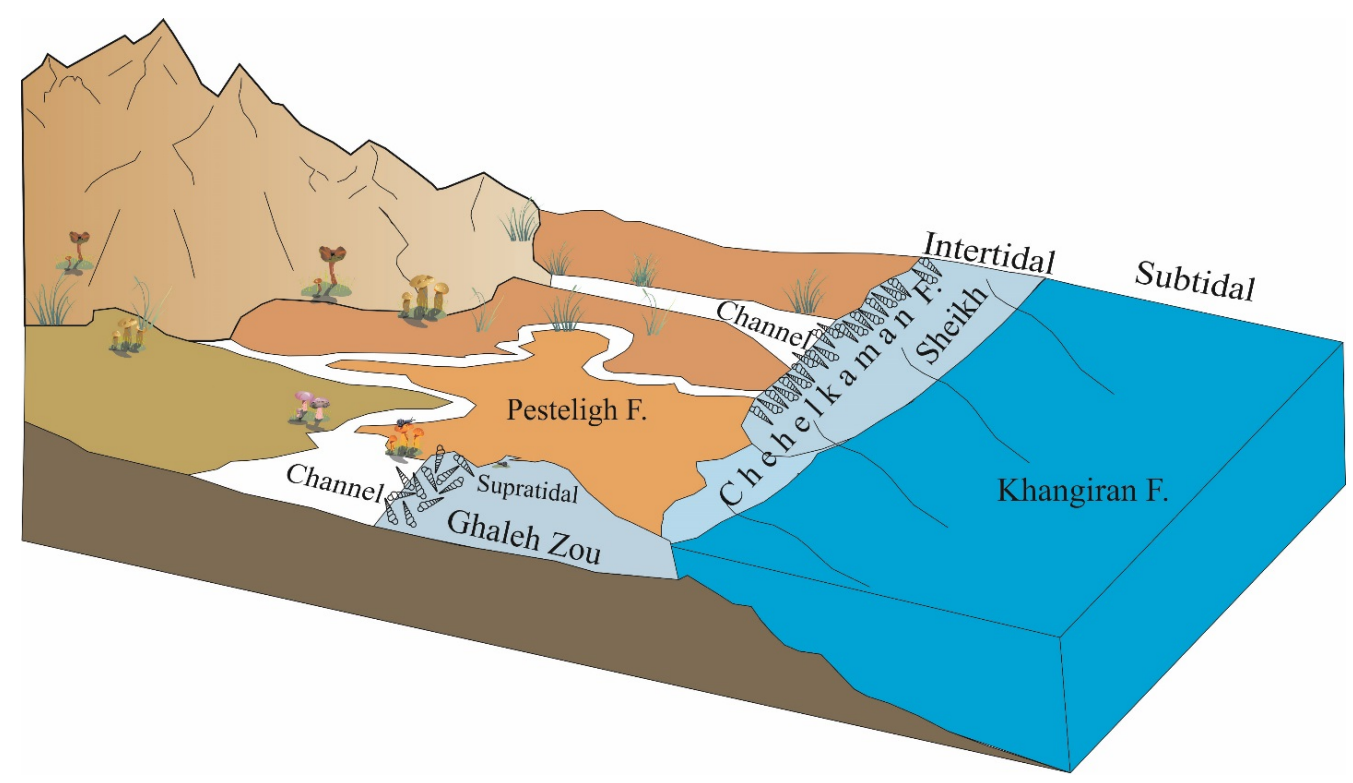


sils led to identification of 12 genera of bivalves and 5 genera of gastropods with a age of Early Eocene (Ypresian). Sedimentary layers containing these fossils were deposited in a shallow intertidal to shallow subtidal environment. Highest occurrence of turritelline gastropods and some oysters such as Pycnodonte and Turkostrea with absolutely disarticulated and fragmented assemblages of oysters, encrustation and bioerosion indicate high levels of nutrients, long residence on the seafloor, low rates of sedimentation and low to very high energy levels for their settlement.

\section{Acknowledgements}

This research was supported by Ferdowsi University of Mashhad, Mashhad, Iran (Grant number 3/40906). We thank the anonymous reviewers for their careful reading of our manuscript and their insightful comments and suggestions.

\section{References}

Afshar-Harb, A., 1969, A brief history of geological exploration and geology of the Sarakhs area and the Khangiran gas field: Iranian Petroleum Institute Bulletin, 37, 86-96.

Afshar-Harb, A., 1979, The stratigraphy, tectonics and petroleum geology of the Kopet-Dagh region, Northeast Iran: London, UK, University of London, $\mathrm{PhD}$ dissertation.

Afshar-Harb, A., 1982, Geological map of Sarakhs, scale 1: 250,000: Ministry of Petroleum, National Iranian Oil Company, Exploration and Production.

Afshar-Harb, A., 1994, Geology of Iran: Geology of Kopet-Dagh. In: Hushmandzadeh A. (Ed.): Treatise on the Geology of Iran: Geological Survey of Iran, Tehran, 1-275 (in Persian).

Allmon, W.D., 1988, Ecology of Recent Turitelline Gastropods (Prosobranchia, Turritellidae):
Current Knowledge and Paleontological implications: Palaios, 3(3), 259-284. https://doi. org $/ 10.2307 / 3514657$

Allmon, W.D., 1992, Role of nutrients and temperature in extinction of turritelline gastropods in the northwestern Atlantic and northeastern Pacific: Palaeogeography, Palaeoclimatology, Palaeoecology, 92(1-2), 41-54. https://doi. org/10.1016/0031-0182(92)90134-q

Allmon, W.D., 1994, Patterns and processes of heterochrony in lower Tertiary turritelline gastropods, U. S. Gulf and Atlantic coastal plains: Paleontology, 68(1), 80-95. https://doi. org/10.1017/s0022336000025610

Allmon, W.D., 1996, Evolution and systematics of Cenozoic American Turritellidae (Gastropoda) I. Paleocene and Eocene species related to "Turritella mortoni Conrad" and "Turritella humerosa Conrad" from the U.S. Gulf and Atlantic Coastal Plains: Palaeontographica Americana, 59, 1-134.

Allmon, W.D., 2007, Gretaceous marine nutrients, greenhouse carbonates, and the abundance of turritelline gastropods: Geology, 115(5), 509 524. https://doi.org/10.1086/519775

Allmon, W.D., 201 1, Natural History of Turritelline Gastropods (Cerithiodea: Turritellidae): A Status Report: Malacologia, 54(1-2), 159-202. https://doi.org/10.4002/040.054.0107

Allmon, W.D., Knight, J.L., 1993, Paleoecological significance of a turritelline gastropod dominated layer in the Cretaceous of South Carolina: Paleontology, 67(3), 355-360. https:// doi.org/10.1017/s0022336000036830

Allmon, W.D., Spizuco, M., Jones, D., 1995, Taphonomy and paleoenvironment of two turritellid-gastropod rich beds, Pliocene of Florida: Lethaia, 28(1), 75-83. https://doi. org/10.1111/j.1502-3931.1995.tb01594.x

Anton, H.E., 1838-1839, Verzeichniss der Conchylien welche sich in der Sammlung von Herrmann Eduard Anton befinden: Herausgegeben von dem Besitzer. Halle: Anton, 110 p.

Bramlette, M., \& Riedel, W. (1954), Stratigraphic Value of Discoasters and Some 
Other Microfossils Related to Recent Coccolithophores: Journal of Paleontology, 28(4), 385-403.

Berberian, M., King, G.C.P., 1981, Towards a paleogeography and tectonic evolution of Iran: Earth Science, 18(11), 1764-1766. https://doi.org/10.1139/e81-162

Berggren, W.A., Kent, D.V., Swisher, C.C. III, Aubry, M.P., 1995, A revised Cenozoic geochronology and chronostratigraphy, in Berggren, W., Kent, D.V., Aubry, M.P., Hardenbol, J., (eds.), Geochronology, Time Scales and Global Stratigraphic Correlation: A Unified Temporal Framework for an Historical Geology: Tulsa, Okla, USA, Society of Economic Paleontologists and Mineralogists, 54, 129-212.

Berizzi Quarto di Palo, A., 1970, Paleogene pelecypods from Kataghan and Badakhshan (North-East Afghanistan), in Desio, A. (ed.), Fossils of North-East Afghanistan: Italian Expeditions to the Karakorum (K2), and Hindu Kush, Brill, Leiden, IV, 2, 161-240.

Berner, R.A., 1994, Geocarb II: A revised model for atmospheric CO2 over Phanerozoic time: American Journal of Science, 294(1), 56-91. https://doi.org/10.2475/ajs.294.1.56

Böhm, J., 1899, Über einige Fossilien aus Buchara: Zeitschrift der Deutschen Geologischen Gesellschaft, 51, 465-470.

Bolourchi, M.H., Mehr Parto, M.,Afshar-Harb, A., 1987, Geological map of Bojnoord, scale 1:250,000: Geological Survey of Iran.

Bouchet, P., 2012, Nuculidae, in De Broyer, G., Clarke, A., Koubbi, P., Pakhomov, E., Scott, F., Vanden Berghe, E. \& Danis, B., (eds.), The SCAR-MarBIN Register of Antarctic Marine Species (RAMS): http://www.marinespecies. org/rams/aphia.php?p5taxdetails\&id5204.

Bowles, E., 1939, Eocene and Paleocene Turritellidae of the Atlantic and Gulf coastal plain of North America: Journal of Paleontology, 13, 267-336.

Bown, P.R., (ed.), 1998, Calcareous Nannofossil Biostratigraphy: British Micropaleontology Society Publication Series, Chapman and Hall/ Kluwer Academic, London, 317 p.
Bown, P.R., Young, J.R., 1998, Techniques, in Bown, P.R., (ed.), Calcareous Nannofossil Biostratigraphy: Chapman and Hall, Kluwer Academic Publishers, London, England, pp. 16-28.

Bramlette, M. N., \& Wilcoxon, J.A., 1967, Middle Tertiary calcareous nannoplankton of the Cipero Section, Trinidad, W.I.: Tulane Studies in Geology and Paleontology, 5, 93-131.

Bramlette, M.N., Sullivan, F. R., 1961, Coccolithophorids and related nannoplankton of the Early Tertiary in California: Micropaleontology, 7(2), 129- 174. https:// doi.org/10.2307/1484276

Bressan, G.S., Palma, R.M., 2010, Taphonomic analysis of fossil concentrations from $\mathrm{La}$ Manga Formation (Oxfordian), Neuquén Basin, Mendoza Province, Argentina: Journal of Iberian Geology 36(1), 55-71.

Brett, C., Baird, G., 1986, Comparative Taphonomy: A key to paleoenvironmental interpretation based on fossil preservation: Palaios, 1(3), 207227. https://doi.org/10.2307/3514686

Bronnimann, P., Stradner, H., 1960, Die Foraminiferen- und Discoasteridenzonen von Koba und ihre interkontinentale Korrelation: Erdoel. 76, 364- 369.

Buryakovsky, L.A., Chilinger, G.V., Aminzadeh, F., 2001, Petroleum Geology of the South Caspian Basin: Boston, Massachusetts, USA, Gulf Professional Publishing.

Callapez, P.M, Gil, J., García-Hidalgo, J.F., Segura, M., Barroso-Barcenilla, F., Carenas, B., 2015, The Tethyan oyster Pycnodonte (Costeina) costei (Coquand, 1869) in the Coniacian (Upper Cretaceous) of the Iberian Basin (Spain): Taxonomic, palaeoecological and palaeobiogeographical implications: Palaeogeography, Palaeoclimatology, Palaeoecology, 435, 105-117. https://doi. org/10.1016/j.palaeo.2015.05.011

Chavan, A., 1942, Sur deux nouveaux groups de Lucinidae: Compte rendu sommaire des séances de la Société Géologique de France, 61-63. 
Cosel, R., 2006, Taxonomy of West African bivalves VIII. Remarks on Lucinidae, with descriptions of five new genera and nine new species: Zoosystema, 28: 805-851

Cossmann, M., 1910, Faune pliocénique de Karikal (Inde française): Journal de Conchyliologie, 58, 34-86.

Cossmann, M., 1918, Éocène de Bretagne. Faune de Bois-Gouët. Atlas paléontologique: Hermann \& Fils, Paris, p. 1-19.

Cuvier, G, 1795, Description de deux especes nouvelles d'insects. Magasin Encyclopedique, ou:Journal des Science, des Letters et des Arts, 1, 205- 207.

Dall, W.H., 1889, A preliminary catalogue of the shell-bearing marine mollusks and brachiopods of the southeastern coast of the United States, with illustrations of many of the species: United States National Museum Bulletin, 37, 1-221.

Dall, W.H., 1902, Synopsis of the family Veneridae and of the North American Recent species: Proceedings of the United States National Museum, 26(1312), 335-412. https://doi. org/10.5479/si.00963801.26-1312.335

d'Archaic, L.V., Haime, J., 1854, Description des animaux fossiles du groupe nummulitique de l'Inde precede dun resume geologique et dune monograph des nummulites: Bulletin de la Société Géologique de France, 2, 378-384.

Davies, A.M., 1935, Tertiary faunas, a text-book for oilfield paleontologists and students of geology. Revised in 1971 by F. E. Eames. London: George Allen and Unwin, 1, 1-571.

Deflandre, G., 1947, Surquelques microorganismes planctoniques des silex Jurassiques: Institut océanographique, Monaco, Bulletin, 921, 1-12.

Deflandre, G., 1959, Sur les nannofossiles calcaires et leur systématique. Revue de Micropaléontologie, 2, 127-152.

Deflandre, G., Fert, C., 1954, Observations sur les Coccolithophorides actuels et fossiles en microscopie ordinaire et electronique: Annales de Paléontologie, 40, 115-76.
Dickens, G.R., Castillo, M.M., Walker, J.C.G., 1997, A blast of gas in latest Paleocene: simulating firstorder effects of massive dissociation of oceanic methane hydrate: Geology, 25, 259-262.

Dockery, D.T., 1980, The invertebrate macro paleontology of the Clarke County, Mississippi area: Mississippi Department of Natural Resources, Bureau of Geology, 122, 1-387.

Dickens, G.R., O’Neil, J.R., Rea, D.K., Owen, R.M., 1995, Dissociation of oceanic methane hydrate as a cause of the carbon isotope excursion at the end of Paleocene: Paleoceanography, 10(6), 965-971. https:// doi.org/10.1029/95pa02087

Dorsey, R.J., Kidwell, S.M., 1999, Mixed carbonate siliciclastic sedimentation on a tectonically active margin: Example form the Pliocene of Baja California Sur, Mexico: Geology 27(10), 935-938. https://doi.org/10.1130/0091$7613(1999) 027<0935:$ mcssoa $>2.3$. co;2

Dorsey, R.J., Umhoefer, P.J., 2000, Tectonic and eustatic control son sequence stratigraphy of the Pliocene Loreto basin, Baja California Sur, Mexico: Geological Society of America Bulletin, 112(2), 177-199. https://doi. org/10.1130/0016-7606(2000)112<0177:ta ecos $>2.3 . \operatorname{co} ; 2$

Fischer de Waldheim, G., 1835, Lettre à M. le Baron de Férussac sur quelques genres de coquilles du Muséum-Demidoffet en particulier sur quelques coquilles fossiles de la Crimée: Bulletin de la Société Impériale des Naturalistes de Moscou, 8, 99-123.

Fleming, J., 1828, History of British animals, exhibiting the descriptive characters and systematical arrangement of the genera and species of quadrupeds, birds, reptiles, fishes, mollusca, and radiata of the United Kingdom; including the indigenous, extirpated, and extinct kinds, together with periodical and occasional visitants. Edinburgh (Bell \& Bradfute) \& London (J. Duncan), i-xxii, 1-565. 
Fürsich, F., Pandey, D.K., 1999, Genesis and environmental significance of Upper Cretaceous Shell concentrations from the Cauvery Basin, southern India: Palaeogeography, Palaeoclimatology, Palaeoecology, 145(1-3), 119-139. https:// doi.org/10.1016/s0031-0182(98)00099-6

Fürsich, F.T., Oschmann, W., 1993, Shell beds as tools in basin analysis: the Jurassic of Kachchh, western India: Geological Society, 150(1), 169- 185. https://doi.org/10.1144/ gsjgs. 150.1.0169

Gale, A.S., Jeffery, P.A., Huggett, J.M., Connolly, P., 1999, Eocene inversion history of the Sandown Pericline, Isle of Wight, southern England: Geological Society of London, 156(2), 327-339. https://doi.org/10.1144/ gsjgs. 156.2.0327

Garzanti, E., Gaetani, M., 2002, Unroofing history of late Paleozoic magmatic arcs within the Turan Plate (Tuarkyr, Turkmenistan): Sedimentary Geology, 151(1-2), 67-87. https://doi.org/10.1016/ s0037-0738(01)00231-7

Gekker, R.F., Osipova, A.I., Belskaya, T.N., 1962, The Ferghana Bay of the Paleogene Sea of Central Asia, its history, sediments, fauna, flora, conditions of existence and the development: Moscow, Russia, Iz-vo Akademiya Nauk SSSR. (in Russian).

Ghaemi, F., 2004, Geological map of Kakli, scale 1: 100,000: Geological Survey of Iran.

Goldfuss, G.A., 1820, Handbuch der Zoologie, in Schubert, G.H., (ed.), Handbuch der Naturgeschichte, zum Gebrauch bei Vorlesungen. Erste Abteilung 1-696, Zweite Abteilung: i-xxiv, 1-510.

Gordillo, S., Bayer, M.S., Boretto, G., Charó, M., 2014, Taphonomy, in Mollusk shells as bio-geoarchives. Evaluating environmental changes during the Quaternary: New York, USA, Springer International Publishing, 7-14. https:// doi.org/10.1007/978-3-319-03476-8_2

Gran, H.H., Braarud, T., 1935, A quantitative study of the phytoplankton in the Bay of Fundy and the Gulf of Maine (including observatons on hydrography, chemistry and turbidity): Biology Board Canada, 1(5), 279-467. https://doi. org/10.1139/f35-012

Gray, J.E., 1824, In: R.C. Moore, (ed.), Treatise on Invertebrate Paleontology. Part N: Mollusca 6, Bivalvia. Geological Society of America \& University of Kansas Press, Boulder, Colorado \& Lawrence, Kansas. N700-N702.

Gray, J.E., 1847, A list of genera of Recent Mollusca, their synonyms and types: Proceedings of the Zoological Society of London, 15, 129- 219.

Griffin, M., Casadio, S., Parras, A., 2005, Maastrichtian and Danian species of Turkostreini (Ostreidae, Crassostreinae) from the Neuquén Basin, Argentina: Ameghiniana, 42, 257-276.

Guettard, J.E., 1770. Memoires sur differentes parties des science et arts: Tome second. 1-350.

Hadavi, F., Senemari, S., 2002, Biostratigraphic property of Khangiran Formation based on Calcareous nannofossils in the east of Chehelkaman syncline: Geoscience, 33, 90112. (In Persian).

Halder, K., Sinha, P., 2014, Some Eocene Cerithioids (Gastropoda, Mollusca) from Kutch, Western India, and Their Bearing on Palaeobiogeography of the Indian Subcontinent: Paleontology, Hindawi, 1-11. https://doi.org/10.1155/2014/673469

Haq, B.U., 197 1, Paleogene calcareous nannoflora Parts I- IV: Stockholm Contribiution Geology, 25, 1-158.

Harzhauser, M., Mandic, O., 2001, Late Oligocene Gastropods and Bivalves from the Lower and Upper Austrian Molasse Basin, in Piller, W.E., \& Rasser, M.W., (eds.), Paleogene of the Eastern Alps: Schriftenreihe der Erdwissenschaftlichen Kommissionen / Österreichische Akademie der Wissenschaften, Wien, 14, 671-795.

Hay, W.W., Mohler, HP., Roth, P.H., Schmidt, R.R., Boudreaux, J.E., 1967, Calcareous nannoplankton zonation of the Cenozoic 
of the Gulf Coast and Caribbean-Antillean area, and transoceanic correlation: Gulf Coast Association of Geological Societies, 17, 428-480.

Hay, W.W. \& Towe, K.M. 1962 (1962). Electron microscope examination of some coccoliths from Donzacq (France) : Eclogae Geologicae Helvetiae 55, 497-517.

Hertlein, L.G., Jordan, E.K., 1927, Paleontology of the Miocene of Lower California, California: Academy of Science Proceedings, ser. 4, 16 (19): 605-647.

Houbrick, R.S., 1992, Monograph of the genus Cerithium Bruguiere in the Indo-Pacific(Cerithiidae: Prosobranchia): Smithsonian Contributions to Zoology, 510, 1-211. https://doi.org/10.5479/ si.00810282.510

Kachhara, R.P., Jodhawat, R.L., Bigyapatidevi, 201 1, Molluscan biostratigraphy of the Paleogene sediments around Lakhpat, Kachchh, Gujarat, India: Paleontological Society of India, 56, 17-28.

Kamptner, E., 1963, Coccolithineen- Skelettreste aus Tiefseeablagerungen des Pazifischen Ozeans. Annalen des Naturhistorischen Museums in Wien, 66. 139- 204.

Karagjuleva, J.D., 1964, Les fossiles de Bulgarie. Fosilitena BlgarijaVI a. Paléogene Mollusca. Blgarska Akademijananaukite (Sofija), 1-270.

Kecskemétiné-Körmendy, A., 1972, A DorogiMedenceeocén mollusca faunaja: Annals of the Hungarian Geological Institute, 55 (2), 143-285 + Tab. 1-45.

Kerans, G., Bebout, D., Kempter, K., 1994, Cycle hierarchy and sequence framework for predicting reservoir heterogeneity styles e Fredericksburg Division, Cretaceous (Albian) of the Austin Area, in Strata Model Conference Fieldtrip Guidebook: Bureau of Economic Geology, University of Texas, Austin.

Kidwell, S.M., Fiirsich, F.T., Aigner, T., 1986, Conceptual framework for the analysis and classification of fossil accumulations: Palaios, 1(3), 228-238. https://doi. org/10.2307/3514687
Kirkland, B.L., Banner, J.L., Moore, C.H., Hoffman, C., Pursell, B., Vasquez, R., 1996, Cretaceous Cyclic Platform Carbonates of Central Texas, in Geological Society of America, South Central Section, Field Trip Guidebook (Field Trip \#3), 36 p.

Kljušnikov, M.N., 1958, Stratigrafijai fauna nižnetretičnihotloženij Ukraini. Akad. Nauk Ukrainskoj SSR, Kiev. Trudy Paleontologicheskogo Instituta Akademiya Nauk SSSR,. 13, 1-548.

Lamarck, J.B., 1809, Mémoires sur les fossils des environs de Paris. Annales du Muséum National d'Histoire Naturelle (Paris) Volumes 1-14; reprinted 1978 by the Paleontological Research Institution, Ithaca, New York.

Lamarck, J.B.D., 1799, Prodrome d'une nouvelle classification des coquilles: Comprenant une rédaction appropriée des caractères génériques, et l'établissement d'un grand nombre de genres nouveaux. Mémoires de la Société d'Histoire Naturelle de Paris, 1, 63-91. (In French).

Lan, X., 1997, Paleogene bivalve communities in the western Tarim basin and their paleoenvironmental implications: Paleoworld, 7, 137- 157.

Leckie, R.M., 1989, A paleoceanographic model for the early evolutionary history of planktonic foraminifera: Paleogeography, Paleoclimatology, Paleoecology, 73(1-2), 107-138. https://doi. org/10.1016/0031-0182(89)90048-5

Lescinsky, H.L., Edinger, E., Risk, M.J., 2002. Mollusc shell encrustation and bioerosion rates in a modern epeiric sea: taphonomy experiments in the Java Sea, Indonesia: Palaios, 17(2), 171-191. https://doi. org/10.1669/0883-1351(2002)017<0171:ms eabr>2.0.co;2

Linnaeus, C., 1758, (1 Jan.) [ref. 2787]. Systema Naturae, ed. X. (Systema naturae per regna trianaturae, secundum classes, ordines, genera, species, cum characteribus, differentiis, synonymis, locis. Tomus I. Editiodecima, reformata.) Holmiae [Stockholm]. 1-824 pp. 
Locker, S., 1973, Coccolithineen aus dem Palaogen Mitteleuropas: Palaöbotanik, 3, 735- 836.

Lovén, S.L., 1847, Malacozoologii: Öfversigtaf Kongliga Vetenskaps Akademiens, Förhandlingar, 4, 175-199 (In Swedish).

Machalski, M., 1988, Redescription of a Danian oyster pycnodonte simile (Pusch, 1837) from Poland: Acta Paleontologica Plonica, 33, 73- 83.

Martini, E., 1971. Standard Tertiary and Quaternary Calcareous Nannoplankton Zonation, in Farniacci, A. (ed.), Proceedings, 2th International Conference on Planktonic Microfossils. Rome, Italy: Edizioni Tecnoscienza, 2, 739-785.

Martini, E., 1976, Cretaceous to Recent calcareous nannoplankton from the Central Pacific Ocean (DSDP Leg 33), in Schlanger, S.O., Jackson, E.D., et al., Deep Sea Drilling Project Initial Reports, 33: 383-423.

Mathur, N.S., 1975, Mollusca from the Subathu Formation (Upper Palaeocene-Middle Eocene): Simla Hills: Bulletin - Indian Geologists' Association, 8, 1-40.

Mathur, N.S., Juyal, K.P., 2000, Atlas of Early Paleogene invertebrate fossils of the Himalayan Foothills belt: Dehra Don, India, Wadia Institute of Himalayan Geology.

Ménard de la Groye, M., 1807, Mémoire sur un nouveau genre de coquille de la famille des solénoides: Annales du Muséum d'Histoire Naturelle, 9, 131-139.

Monterosato, T.A., 1889, Coquilles marines Marocaines: Journal de Conchyliologie, 37(1), 20-40; 37(2), 112-121.

Montfort, P., 1808-1810, Conchyliologie systématique et classification méthodique des coquilles: Paris, France, Schoell, 2, 1-692.

Moore, E.J., 1984, Tertiary Marine pelecypoods of California and Baja California: PropeamussiidaeandPectinidae: Washington, USA, United States Government Printing Office.

Morales-Ortega, P., González-Barba, G., NavaSánchez, E.H., Vera-Dimas, D.R., 2016, New
Eocene bivalves from Bateque Formation, Baja California Sur, Mexico: Paleontología Mexicana, 5, 1-19.

Moshirfar, Y., Mahdavi, M., Ghasemi-Nejad, E., Ashouri, A., 2013, Eocene climatic events recorded in dinoflagellate cyst assemblages from the Kopeh-Dagh Basin, NE Iran; a statistical approach: Arabian Journal of Geoscience, 8(2), 867-876. https://doi. org/10.1007/s12517-013-1184-y

Muller, A.H., 1951, Grundlagen der biostratinomie. Abhandlungen der Deutschen Akademie Der Wissenschaffen Berlin, Klase Mathematik und allgemeine Naturwissenschaffen: Jahrgang, 3, 1-147.

Neumayr, M. 1884. Zur Morphologie des Bivalvenschlosses: Sitzungsberichte der kaiserlichen akademie der wissenschaften in wien, 88 (1), 385-418.

Newell, N.D., 1965, Classification of the Bivalvia: American Museum Novitates, 2206, 1-25.

Okada, H., Bukry, D., 1980, Supplementary modification and introduction of code numbers to the low-latitude coccolith biostratigraphic zonation: Marine Micropaleontology, 5 (3): 321-325.

Okan, Y. Hoşgör, İ., 2009. Early Eocene (middlelate Cuisian) Molluscs Assemblage from the Harpactocarcinid Beds, in the Yoncal Formation of the Cankır Basin, Central Anatolia, and Implications for Tethys Paleogeography: Geological Bulletin of Turkey, 52 (1), 1-30.

Okan, Y., Hoşgör, I., 2008, The Ampullinid Gastropod Globularia (Swainson 1840) from the Late Thanetian-Early Ilerdian of Kırkkavak Formation (Polatl-Ankara) of the Tethyan Realm: Turkish Journal of Earth Sciences, 17, 785-801.

Perch-Nielsen, K., 1971. Durchsicht Tertiarer Coccolithen: Proceedings II Planktonic Conference, Roma, 2, 939-980.

Perch-Nielsen, K., 1984, Validation of new combinations: INA Newsletter, 6 (1), 42-46.

Perch-Nielsen, K., 1985. Cenozoic Calcareous Nannofossils, in Bolli, H.M., Saunders, JB., 
Perch-Nielsen, K., (eds.), Plankton Stratigraphy:

Cambridge University Press, 427-554.

Perch-Nielsen, K., Sadek, A., Barakat, M.G., Teleb, R. 1978, Late Cretaceous and Early Tertiary calcareous nannofossil and planktonic Foraminifera Zones from Egypt: Annales des Mines et de la Geologie (Tunisia), Actes du VI Colloque African de Micropaleontologie, Tunis, 28 (2), 337-403.

Proto Decima, F., Roth, P.H., Todesco, L., 1975, Nannoplancton calcareo del Paleocene e dell' Eocene della sezione di Possagno. Palaöntology, 97, 35- 55.

Rafinesque, C.S., 1815, Analyse de la nature, ou tableau de l'université des corps organisés: Palerme, 1-224.

Ravizza, G., Norris, R.N., Blusztajn, J., 2001, An osmium isotope excursion associated with the late Paleocene thermal maximum: Evidence of intensified chemical weathering: Paleoceanography, 16(2), 155-163. https:// doi.org/10.1029/2000pa000541

Rivandi, B., Vahidinia, M., Nadjafi, M., Mahboubi, A., 2012, Shallow benthic foraminifera from the Early Paleogene carbonate platform, northeastern Iran: Sociedad Española de Paleontología y Simposios, Valencia, 107-109.

Rivandi, B., Vahidinia, M., Nadjafi, M., Mahboubi, A., Sadeghi, A., 2013, Biostratigraphy and Sequence Stratigraphy of Paleogene Deposits in Central K opet-Dagh Basin (NE of Iran): Journal of Geological Research, 1-12. https://doi.org/10.1155/2013/892198

Robert, A., Letouzey, J., Kavoosi, M., Sherkati, S., Müller, C., Vergés, J., Aghababaei, A., 2014, Structural evolution of the Kopeh Dagh foldand-thrust belt (NE Iran) and interactions with the South Caspian Sea Basin and Amu Darya Basin: Marine and Petroleum Geology, 57, 68- 87. https://doi.org/10.1016/j. marpetgeo.2014.05.002

Romanovsky, G.D., 1878, Materialy dlya geologiy Turkestanskago kraya: St. Petersbourg, Russia, Academie Impériale des Sciences, 1, viii-167.
Saadat-Mehri, V., Nadjafi, M., Moussavi-Harami, R., 2012, Determine the sequences of the Neogene sedimentary environment in southwestern Mozdoran and Tabadakan in East of Kopet-Dagh basin: the first National Conference of Geology, Shiraz, Islamic Azad University of Shiraz. (In Persian).

Sacco, F., 1897, Pelecypoda (Ostreidae, Anomiidae e Dimyidae) of L. Bellardi \& Federico Sacco, 1872-1904, I molluschideiterreni Terziarii de Piemonte e della Liguria. Carlo Clausen, Torino. 1-66.

Sahni, A., Kumar, K., 1983, Faunal evidence for the withdrawal of the Tethys in the Lesser Himalaya, Northwestern India: Bollettino della Società Paleontologica Italiana, 22, 77-86.

Salahi, A., Vahidinia, M., 2011, Description, paleoecology and paleobiogeography of Khangiran formation oysters, in the Chehelkaman synclinal section, East of KopetDagh basin: Sedimentary Facies, 4(1), 54-62 (in Persian).

Salahi, M.A., 2011, Planktonic foraminifera biostratigraphy of Khangiran Formation on Chehelkaman Syncline section, Eastern KopetDagh: Mashhad, Iran, Ferdowsi University of Mashhad, M.Sc. Dissertation (in Persian).

Schafer, W., 1972, Ecology and paleoecology of marine environments: Oliver and Boyd, Edinburgh, 67, 170-177.

Schiller, J., 1930, Coccolithineae, in Dr. L. Rabenhorst's Kryptogamen- flora von Deutschland, Österreich und der Schweiz: Akademische Verlagsgesellschaft, Leipzig, 10, 89-267.

Schroeder, T.A., 1992, A palynological zonation for the Paleocene of the North Sea Basin: Micropalaeontology, 11, 113-126. https:// doi.org/10.1144/jm.11.2.113

Seilacher, A., 1959, Vom Leben der Trilobiten: Naturwissenschaften, 46, 389-393.

Seilacher, A., 1973, Fabricational noise in adaptive morphology: Systematic Zoology, 22(4), 451-465. https://doi. org/10.2307/2412952 
Seilacher, A., 1984, Constructional morphology of Bivalves: evolutionary pathways in primary versus secondary soft-bottom dwellers: Palaeontology, 27 (2), 207-237.

Shamari, I.A., 1963, Certain forms of Upper Cretaceous and Paleogene coccoliths and discoasters from the southern Russian platform: Izvestiya Vysshikh Uchebn. Zaved. Geology. I Razv., 6 (4), 27- 40.

Solander, D.C., in Brander, G., (ed.), 1766, Fossilia Hantoniensia collectaet in Musæo Brittanicodeposita. Londini, 1-43.

Sowerby, J.C., 1812-1845, The mineral Conchology of Great Britain: London, UK, Benjamin Meredith, 7, 1-648.

Squires, L.R., 2012, Additions to Late Cretaceous Shallow-marine limopsid bivalves and neogastropods from california: Contributions in Science, 520, 5-14.

Stanley, S., 1970, Relation of shell form to life habit of the Bivalvia (Mollusca): Geological Society of America Memoir, 125, 1-296. https://doi.org/10.1130/ mem125-p1

Stenzel, H.B., 1971, In: Moore, R.G., (Ed.). Treatise on Invertebrate Paleontology, Part N, 3 (Oysters), N953-N1224.

Stradner, H., 1959, First report on the discoasters of the Tertiary of Austria and their stratigraphic use: Proceeding of 5th World Petrolium Congress, New York. 1. 1081- 1095.

Stradner, H., Edwards, A.R., 1968, Electron microscopic studies on Upper Eocene coccoliths from Oamaru Diatomite, New Zealand: Jahrbuch Der Geologischen Bundesanstalt, Special volumen, 13, $1-66$.

Sullivan, F.R., 1964, Lower Tertiary nannoplankton from the California Coast Ranges. I. Paleocene: University California Publication, Geology science, 44, 163- 227.

Swainson, W., 1835. The elements of modem conchology; briefly and plainly stated for the use of students and travellers: Baldwin \& Cradock, London, $62 \mathrm{p}$.

Swainson, W., 1840, A Treatise on Malacology, or Shells and Shell-fish: London, UK, Longman.

Tomašových, A., 2006, Linking taphonomy to community-level abundance: Insights into compositional fidelity of the Upper Triassic Shell concentrations (Eastern Alps): Palaeogeography, Palaeoclimatology, Palaeoecology, 235(4), 355-381. Torigoe, K., 1981, Oysters in Japan: Journal of ScienceHiroshima University Series B Division 1, 291-481. Toulmin, L.D., 1969, Paleocene and Eocene guide fossils of the eastern Gulf coast region: Transactions of the Gulf Coast Association of Geological Societies, 19, 465-487.

Vialov, O.S., 1936, Sur la classification des huitres: URSS Academy of Sciences, Comptesrendus (Doklady), new series, 4(13), 17-20.

Vialov, O.S., 1938, On the Middle Asiatic Fatina Vialov and Turkostrea Vialov. Izv. AK. Nauk USSR, 1518, Moskva.

Vialov, O.S., 1948, Paleogenovie Ustrici Tadzhikskoi Depressii (Paleogene Ostreids from Tajik Depression), Trudy VNIGRI, Leningrad.

Waller, T.R., 2011,Neogenepaleontology of the northern Dominican Republic. 24. Propeamussiidae and Pectinidae (Molluscaj Bivalvia: Pectinoidea) of the Cibao Valley: Bulletins of American Paleontology, 2011 (381), 1-205.

Waller, T.R., 1969, The evolution of the Argopecten gibbus stock (Mollusca: Bivalvia), with emphasis on the Tertiary and Quaternary species of eastern North America: Journal of Palaeontology, 43 (5), 1-125. https://doi.org/10.1017/ s0022336000062466

Wallich, G.C., 1877, Observations on coccosphere: Annals \& Magazine of Natural History, 16, 322- 339 .

Wilmsen, M., Fürsich, T.,Emami, K.S., Majidifard,M.R., Taheri, M.R., 2009, The Cimmerian Orogeny in northern Iran: tectono-stratigraphic evidence from the foreland: Terra Nova, 21(3), 211-218. https:// doi.org/10.1111/j.1365-3121.2009.00876.x

Wood, R., 1993, Nutrients, predation and the history of reef-building: Palaios, 8(6), 526-543. https://doi. org/10.2307/3515030 